DEMOGRAPHIC RESEARCH

VOLUME 40, ARTICLE 34, PAGES 975-1014

PUBLISHED 17 APRIL 2019

https:/www.demographic-research.org/Volumes/Vol40/34/

DOI: 10.4054/DemRes.2019.40.34

Research Article

\title{
Housing consequences of divorce and separation in a 'super home ownership' regime: The case of Hungary
}

\section{Lívia Murinkó}

This publication is part of the Special Collection on "Separation, Divorce, and Residential Mobility in a Comparative Perspective," organized by Guest Editors Júlia Mikolai, Hill Kulu, and Clara Mulder.

\section{(C) 2019 Livia Murinkó.}

This open-access work is published under the terms of the Creative Commons Attribution 3.0 Germany (CC BY 3.0 DE), which permits use, reproduction, and distribution in any medium, provided the original author(s) and source are given credit.

See https://creativecommons.org/licenses/by/3.0/de/legalcode. 


\section{Contents}

1 Introduction 976

$2 \quad$ Theory and background 977

$2.1 \quad$ Housing transitions and family dynamics 977

2.2 Divorce and separation in Hungary 980

$2.3 \quad$ Housing and residential mobility in Hungary 981

2.4 The role of the parental home in Hungary: Leaving, staying, and 983

$2.5 \quad$ Research questions and hypotheses 984

2.5.1 Cohabitation hypothesis 985

$\begin{array}{ll}\text { 2.5.2 Status hypothesis } & 985\end{array}$

2.5.3 Parental home hypotheses 985

2.5.4 Tenure hypothesis 986

$3 \quad$ Data and methods 986

3.1 The Hungarian Generations and Gender Survey 986

$\begin{array}{lll}3.2 & \text { Variables } & 987\end{array}$

$\begin{array}{lll}3.3 & \text { Methods } & 991\end{array}$

$4 \quad$ Results 992

4.1 Who moves: residential change by change in partnership status 992

4.2 Where people move to: Destination housing tenure by change in 998

$5 \quad$ Discussion and conclusions 1002

$\begin{array}{lll}6 & \text { Acknowledgements } & 1004\end{array}$

$\begin{array}{ll}\text { References } & 1005\end{array}$

$\begin{array}{ll}\text { Appendix } & 1011\end{array}$ 


\title{
Housing consequences of divorce and separation in a 'super home ownership' regime: The case of Hungary
}

\author{
Lívia Murinkó ${ }^{1}$
}

\begin{abstract}
BACKGROUND

Partnership dissolution is a major reason for residential mobility and migration for former partners. Moving is more resource-intensive in a 'super home ownership' housing regime like Hungary and may increase the vulnerability of people with low socioeconomic status. This analysis is the first attempt to study the interrelationship between partnership transitions and housing dynamics in a Central and Eastern European country.
\end{abstract}

\section{OBJECTIVE}

We analyse how people adjust their housing situation and place of residence to their changing family circumstances after partnership dissolution in Hungary.

\section{METHODS}

We study change in partnership status and housing between 2008 and 2012 using the Hungarian Generations and Gender Survey $(n=5,408)$ with descriptive analysis and logistic regression models. The role of cohabitation and marriage, coresidence with parents, housing tenure, and socioeconomic status receives special attention.

\section{RESULTS}

Former couples move more often after divorce than separation from cohabitation, but divorcees who lived with their parents before union dissolution tend to stay. For men, returning to the parental household is a common solution. Both high and low socioeconomic status may increase the probability of moving after separation or divorce.

\section{CONCLUSIONS}

Home ownership is a motivating factor for moving after divorce in Hungary. Parental household provides an important 'safety net' and in some cases a long-term solution for couples in an inflexible housing market where the system of public housing is missing and private rental is expensive.

\footnotetext{
${ }^{1}$ Hungarian Demographic Research Institute, Budapest, Hungary. Email: murinko@demografia.hu.
} 
Murinkó: Housing consequences of divorce and separation in a 'super home ownership' regime

\section{CONTRIBUTION}

We emphasise the importance of differentiating between the dissolution of marriages and cohabitations and considering coresidence with parents both as the origin and destination of moves.

\section{Introduction}

The past few decades have witnessed rising divorce rates, the growing popularity of unmarried cohabitation, and increasingly fragile partnerships in many developed countries. In this context, what happens after union dissolution has attracted increased scholarly attention (Andreß and Hummelsheim 2009; Leopold 2018), including studies on the housing consequences of divorce and separation (see, for example, Wagner and Mulder 2015 and Cooke, Mulder, and Thomas 2016 for up-to-date summaries of relevant research).

When a cohabiting relationship or a marriage dissolves, by definition one or both of the former partners leave the joint household. These relocations are often urgent, temporary, financially and spatially restricted: while people who split up want to move apart as soon as possible, they may experience multiple moves and live in temporary accommodations before they find suitable housing and settle down again (Feijten and van Ham 2007, 2013). The instability and the reduced housing quality that follows such a move may be a source of stress (Booth and Amato 1993) and may pose vulnerability for people of low socioeconomic status (Theunis, Eeckhaut, and van Bavel 2018).

This paper addresses the issue of residential mobility following union dissolution in a Central and Eastern European country, namely Hungary. Labelled as a 'super home ownership' regime (Stephens 2004), Hungary is characterised by very high rate of owner occupation. Home ownership, especially joint home ownership, is more common among married than cohabiting couples, therefore the housing consequences of union dissolution may also be different. Another important feature of the Hungarian housing regime is the special role of the parental home. Many couples start living together under the parental roof, and returning to the parental household is a common solution in times of difficulty, including partnership dissolution.

Based on research findings mostly from Western Europe, we formulate a series of research questions and hypotheses regarding how divorce and separation may affect residential change in contemporary Hungary. We study differences by partnership type, socioeconomic status, the role of the parental household both as origin and destination, and tenure choice following union dissolution. The empirical analysis is based on data from a large panel survey called the Hungarian Generations and Gender Survey (GGS). 
We compare changes in partnership status and housing situation between two survey waves, 2008 and 2012.

Despite growing international attention, the research area of housing and spatial mobility following partnership transitions is relatively new in the Hungarian context. Using longitudinal data and regression models for analysing the housing consequences of divorce and separation for the first time in Hungary is the first novelty of our study. Second, most studies do not differentiate between the dissolution of a marital and a nonmarital union, while separation from cohabitation and marriage has different consequences for housing quality and tenure (Feijten and van Ham 2010). In this paper we emphasise the importance of distinguishing between the dissolution of married and nonmarried unions in a society where cohabitation and marriage are mostly not alternative partnership forms but different stages of the same process (Hiekel, Liefbroer, and Poortman 2014; Murinkó and Spéder 2015; KSH 2017). Third, coresidence of young adults and their parents is more common in Hungary than in Western and Northern Europe (Iacovou and Skew 2011; Aassve, Cottini, and Vitali 2013; Monostori and Murinkó 2015), and the parental home serves as the most effective safety net after union dissolution. The third contribution of our study is that we also include cases when partners lived together with parents prior to separation and also consider coresidence with parents as a destination of moves. All in all, the special characteristics of the Hungarian housing regime - and its consequences for family solidarity and intergenerational coresidence - make this study a unique contribution to the literature on the interrelationship between partnership and housing trajectories.

\section{Theory and background}

\subsection{Housing transitions and family dynamics}

Research into housing over the life course and its relationship with family dynamics has a long history. The most commonly used general theoretical framework for residential relocations is based on the life course perspective (Mulder and Hooimeijer 1999; Coulter, van Ham, and Findlay 2016). Its basic statement is that residential change incurs important monetary and nonmonetary costs, thus people will move only if it is absolutely necessary or if the benefits outweigh the costs. Some events or transitions trigger residential relocations, depending on microlevel resources and restrictions as well as macrolevel opportunities and constraints. The trigger for moving may come from one of the various life domains or life course trajectories that develop in parallel to the domain of relocations (such as a change in household size or composition, education, or labour market careers). The triggering events create a disequilibrium 
between existing and desired housing, thus motivating an adjustment move to restore equilibrium and improve residential satisfaction.

Motivations for moving and staying often differ by partnership trajectory. People in steady relationships most often move to adjust to changes in household size and composition (e.g., childbirth, adult child leaving the parental home), due to transitions in other life domains (e.g., unemployment, new job etc.), to adjust to needs of family members (e.g., care for an elderly parent), or because they simply want better housing. People with no partner may also move to adjust to transitions in other life domains, to move upwards on the housing ladder, or to become independent from parents if they still live in the parental household. Starting a new coresidential relationship also involves moving. In the case of divorce or separation, moving is necessary for one or both of the former partners. The decision of who moves out following separation is the result of a bargaining process. The partners take into account the possible costs and benefits that moving or staying involve as well as the resources they have (Mulder and Wagner 2010, 2012).

Income and savings are the most important individual resources needed for moving (Mulder and Hooimeijer 1999). Individual restrictions that hinder moving include home ownership, which is most often the main (or only) property of its owners. Household members' attachment to the location also restricts moves (distance to work, school, family, and friends). Divorced or separated people (especially men) often move short distances. This way they stay close to their usual environment and relatives and, most importantly, their nonresident children (Feijten and van Ham 2007, 2013; Mulder and Malmberg 2011; Mulder and Wagner 2012).

On the macro level, people can move only if new accommodation is available (Mulder and Hooimeijer 1999). The range of suitable housing opportunities are limited by their location, size, quality, or price. If moving is urgent (such as in case of a union dissolution), the household is more likely to accept lower quality housing.

Empirical results indeed show that most life course events have a positive effect on the probability of moving, with union formation and dissolution being the most influential ones (Clark 2013; Morris 2017). Compared to couples who are still together and to single people, the divorced and the separated are more likely to change residence (Feijten 2005; Feijten and van Ham 2007; Mikolai and Kulu 2018). This effect is the strongest immediately after separation but still visible three or more years later (Mikolai and Kulu 2018). Studies on housing changes after divorce find a substantial amount of housing mobility and a negative impact of partnership disruption on tenure, quality, size, or neighbourhood. In other words, moving after separation or divorce often involves 'downward moves' on the housing ladder (Sullivan 1986; Feijten 2005; Dewilde 2009). 
The search for suitable housing may take time, and temporary solutions such as shared accommodation or rent-free living with family or friends are quite common. Many people leave owner occupation immediately after divorce or separation, while some (especially women) do so only later, when they face difficulties of coping with housing costs or find that they do not manage to raise the capital necessary to buy their ex-partner's share in the house. Divorce strongly enhances the exit out of home ownership, and it also reduces the likelihood of home ownership in later life (Feijten 2005; Dewilde 2009; Feijten and van Ham 2010; Dewilde and Stier 2014; Thomas and Mulder 2016).

Results regarding gender differences are mixed: studies either do not find any differences or they find that the partner with fewer resources - often the woman - is more likely to move (Mulder and Wagner 2010, 2012; Cooke, Mulder, and Thomas 2016). However, results agree that women are less likely to leave the family home if the couple has children (Dewilde 2009; Mulder and Malmberg 2011; Cooke, Mulder, and Thomas 2016).

Only few studies make a distinction between the dissolution of a marital and a nonmarital union (Feijten and van Ham 2010), while others do not expect considerable differences between them regarding residential change (Feijten and van Ham 2007; Mikolai and Kulu 2018). Studies finding that separation from cohabitation has a larger impact on residential relocation than divorce (Clark 2013; Morris 2017) distinguish between the events of divorce and separation, with married couples first experiencing separation then divorce, and nonmarried couples experiencing separation only. This way separation marks the start of the divorce process and understandably makes moving more likely than the end of the legal process of divorce, which may happen months or even years later. However, separation from cohabitation and marriage has different consequences for housing quality. Those who divorce are likely to experience a larger drop in housing quality than those who split up from cohabitation (Feijten and van Ham 2010). Married couples are more likely to live in better quality housing than cohabiters, therefore they are expected to 'lose more' (Feijten and van Ham 2010).

Previous studies often find that higher socioeconomic status (income or education) is associated with a lower probability of residential change after union dissolution (Mulder and Malmberg 2011; Mulder et al. 2012; Theunis, Eeckhant, and van Bavel 2018). Resources are needed to stay and bear the costs of the joint home without the help of the former partner. If both partners prefer staying, the one with more education or resources may be in a better bargaining position during the decision making process. Moving also has financial and nonmonetary costs in the form of reduced housing quality, uncertainty, or loss of local ties.

The most effective way to reduce the cost of moving in a crisis situation is moving to the parental home. Partnership dissolution increases the likelihood of intergenera- 
tional coresidence even in Sweden, a country where adult children rarely live with their parents (Albertini, Gählen, and Härkönen 2018; see the following papers for results on other countries: Das, de Valk, and Merz 2017; Grundy 2000; Sarkisian and Gerstel 2008; South and Lei 2015; Stone, Berrington, and Falkingham 2014; Sullivan 1986). Men, those with low income, and young persons are the most likely to reenter coresidence with their parents (Das, de Valk, and Merz 2017; Smits, van Gaalen, and Mulder 2010; Albertini, Gählen, and Härkönen 2018; Sullivan 1986).

\subsection{Divorce and separation in Hungary}

Hungary has a long history of relatively liberal divorce legislation and high divorce rates (Oláh 2001). Total divorce rate further increased after 1990, reaching its peak of 0.46 in 2008, and has not decreased below 0.40 since then. About $60 \%$ of dissolving marriages involve minor children, and this rate is decreasing, as more couples without children or with adult children end their marriages. The proportion of divorces after at least 20 years of marriage has also increased (Földházi 2015).

Spousal alimony is very rare and by default the property of the former couple is evenly divided between the divorced spouses (Oláh 2001). Mothers often retain the right to live in the couple's dwelling with the children, while fathers have to find

another accommodation. Courts routinely give custody to the mother (the share of joint physical custody has started to increase only recently), consequently mothers with child(ren) constitute $91 \%$ of single-parent families (Monostori and Murinkó 2015).

We cannot fully understand partnership dissolution without talking about unmarried unions. Unmarried cohabitation has become more common since 1990: in $201613 \%$ of the population aged 15 or more lived in cohabitation (KSH 2017). Cohabiting couples form a heterogeneous group. Two-thirds of those cohabiting are never-married, and one-fourth is divorced (KSH 2017). While it used to be mainly a postmarital living arrangement after divorce or the death of a spouse (Carlson and Klinger 1987), cohabitation before (or instead of) marriage has become part of the standard family trajectory for today's young Hungarians (Murinkó and Spéder 2015).

Cohabitation is more often seen as a stage in the marriage process and not as an alternative to marriage in contemporary Hungary (Hiekel, Liefbroer, and Poortman 2014). A large number of cohabitations turn into marriages within the first few years of the relationship. If the partners do not get married, cohabiting couples break up sooner and more often than either direct marriages or marriages following premarital cohabitation (Földházi 2015). 


\subsection{Housing and residential mobility in Hungary}

The most important feature of the Hungarian housing regime is its very high home ownership rate; Hungary can be described as a 'super home ownership' system (Stephens 2004). In 2011, the overall tenure structure consisted of $92 \%$ owner occupied, $4 \%$ private rental, 3\% municipal (public) rental, and 1\% corporate housing stock (Pittini et al. 2015). The real size of the private rental sector is probably higher than what the official statistics show - due to the widespread practice of tax evasion around $50-80 \%$ of private tenancies are unreported (Hegedüs, Horváth, and Tosics 2014) - but home ownership is undoubtedly the most prominent form of tenure in Hungary.

There are some differences in tenure status by partnership form, but home ownership is the dominant in each partnership group (KSH 2013). In 2011 95\% of married couples and $84 \%$ of cohabiting couples lived in owner occupied dwellings. Around $4 \%$ of married and $14 \%$ of nonmarried couples rented their homes, and other tenure forms were also more common among the cohabiting than among the married $(2.3 \%$ vs. $0.6 \%)$. Another important housing difference between cohabiting and married couples is that married couples are usually joint homeowners. If a married person buys a house or an apartment during the marriage, half of the property automatically belongs to his or her spouse (as opposed to cases when one of the spouses inherited the home or if one partner bought it before getting married). Therefore, in case of a divorce, the former spouses have to sell the house or one partner has to buy the share of the other. Homeownership - often treated as a restriction that hinders moving among steadily partnered or single individuals in both the international and the Hungarian literature - is a possible reason for residential relocation after union dissolution (Wagner and Mulder 2015). Selling and moving is the only option when neither the ex-husband, nor the exwife can or want to buy the share of the other or if none of them can afford staying there and paying the bills (and the mortgage) alone.

In Hungary, private renting is not widely accessible because it is concentrated in cities and the rent is expensive relative to earnings. The housing cost overburden rate (the proportion of the population whose housing costs exceed $40 \%$ of their equivalised disposable income) was $8.5 \%$ in the total population in Hungary, while it was $32.4 \%$ among tenants who rented at market price (Eurostat 2016). Neither tenants nor landlords consider private renting a long-term arrangement; instead it is seen as a 'residual' solution for households who cannot buy their own homes or a temporary accommodation for transitional periods (Hegedüs and Teller 2007). The largest group among private renters are households who recently changed residence, foreign professionals, divorced people, students, and indebted mortgagors (Hegedüs and Horváth 2018). The share of population in private rental dwellings by income shows a U-shaped relationship: higher income households can afford to rent whereas low- 
income households cannot afford to buy (KSH 2016). Despite its low share in the total housing stock, the role of private renting has gained importance in the past decade (Hegedüs and Horváth 2018). Following a move, 10.8\% of households lived in rental accommodation between 1996 and 2003, while 27.9\% of households did so between 2005 and 2015 (KSH 2016).

In Hungary, housing policies favour ownership and much less attention is paid to renters. There are no central government subsidies or housing allowance for private renters. Local (municipal) subsidies are rare, very modest, and limited to very lowincome households (Hegedüs and Horváth 2018). There is a lack of social housing for people with affordability problems and temporary crises (Hegedüs and Teller 2006). In these situations, the only effective safety net is family solidarity, in particular the parental household (Hegedüs and Teller 2007).

Compared to the EU average, the level of internal migration is relatively low in Hungary. During the five-year periods of 2002-2007 and 2007-2012, only 7\% of the adult population moved to another dwelling, while the EU averages were $9 \%$ and $18 \%$, respectively (Eurostat 2016). In Hungary, the crude migration rate slowly increased since 1990 but decreased sharply after the start of the financial crisis in 2008 and increased again only in 2013 (Bálint and Gödri 2015).

When asked about the reason for moving, about every second person named a family-related reason: $21 \%$ moved because they started a cohabiting union or marriage, $12 \%$ did so because their relationship dissolved, and $13 \%$ because they left the parental home to live independently. About every tenth individual chose a work-related reason (more so during the crisis than earlier), and every fourth said that they moved to have a better, larger, nicer, or less expensive house (KSH 2016).

To our knowledge, there has only been one survey in Hungary since 1990 that specifically focused on the housing consequences of divorce. Fielded in 2002/2003, the survey looked at divorcees whose marriage officially ended in 2000 (Földházi 2005). In most of the cases (74\%) only one of the former spouses moved after divorce; in $20 \%$ of the cases both of them moved, and $6 \%$ of the divorced couples still lived under the same roof two years after divorce. Both the former wife and husband moved if both had the opportunity to buy a (smaller) home or if none of them could afford to buy the share of the common house from the former spouse. In other words, people with both high and low income/wealth had financial motivations to move. Women were somewhat less likely (49\%) to move than men (57\%). The highly educated were slightly more likely to move than people with primary education (Földházi 2005).

Tenure seems to be the most important factor affecting the probability of moving after divorce: while $50 \%$ of owners moved, $81 \%$ of divorcees who lived in the home of the former spouse did so, and 44\% moved among those who had lived with their parents as a couple prior to divorce. Overall, $23 \%$ moved to their own homes, $15 \%$ 
rented, and 56\% moved to someone else's house (including the parents). Previous owners, older, more educated, and city-dweller divorcees were the most likely to move to owner-occupied dwellings (Földházi 2005).

\subsection{The role of the parental home in Hungary: Leaving, staying, and returning}

In international comparison Hungary can be placed somewhere in the middle of the continuum between the Northern and the Eastern model of leaving the parental home. The continuum ranges from early homeleaving, small household size and the almost total lack of extended families to late homeleaving, larger households, and more frequent extended families (Iacovou and Skew 2011).

Age norms regarding homeleaving are quite weak in Hungary. People think that young people become too old to still live with their parents at age 30-31, which is a relatively high figure in European comparison. Moreover, 35\% think that there is no upper age limit for men when they are too old to live with parents and $43 \%$ thinks the same for women (Aassve, Arpino, and Billari 2013).

Pretransition Hungary was characterized by relatively early homeleaving (the median age was 24 years for men and 21 years for women) (Murinkó 2013). Trends of postponement and heterogenization started among people born after 1970, and more people do not leave the parental home until the end of their young adult years. Women leave earlier (the median age was 25 years for women and 28 years for men between 2000 and 2008), and more women leave than men, while postponement is stronger among females (Murinkó 2013).

The relationship between homeleaving and partnership formation is strong but gradually weakening as more young people leave the parental home for education- or employment-related reasons. From among the life course events that usually take place during young adulthood, first marriage or the start of the first cohabiting union are still the ones that most often coincide with leaving the parental home. However, it is not uncommon that first partnership precedes first homeleaving. During the last two decades the proportion of those who started a cohabiting union only sometime after having left the parental nest has gradually increased, while the share of people cohabiting in the parental household is still considerable (Murinkó 2013). Every second newly married couple started to live together in the home of his or her parents before 1980 , and this proportion had only slightly decreased until 2000 (from 52\% to $45 \%$ ). This phenomenon was more widespread among people who married at a young age (below 25), who had low education, and lived in villages (Földházi 2005). Two years after divorce $40 \%$ lived in someone else's home, most often the parents. Men with low 
and women with high education were the most likely to move in together with their parents (Földházi 2005).

As a result of delayed homeleaving of young people and a growing tendency to return, the number of young adults living with their parent(s) has increased since 1990 (Monostori and Murinkó 2015). The economic recession has strengthened this trend: between 2007 and 2011, coresidence of young adults and their parents increased by 9.6\% in Hungary, with the largest increase in the 25-29 age group (Aassve, Cottini, and Vitali 2013).

A sizeable share of people beyond their twenties still (or again) live with one or both of their parents: $16 \%$ of women and $27 \%$ of men in their thirties, and $10 \%$ of women and $19 \%$ of men in their forties do so. Not all of them are single: $18 \%$ of young adults living in the parental household are married or cohabiting. Among people aged 30-49 who live with their parents, $21 \%$ are returned divorced or separated parents. Most of them chose this living arrangement for financial and housing reasons and would rather live separately. However, they do not feel that their parents put pressure on them to move (Monostori and Murinkó 2015).

The proportion of those living in three- or multigenerational households continuously decreases in Hungary. However, they form a sizable group among people aged 30-49 and living with parents: $17 \%$ in this group live in a three-generational family. They are relatively educated, their financial situation is average, and their employment rate is high. This household type is more common in villages and small towns, where the average floor space of houses is the largest. Many people in this group probably consider living with parents (and also with partner and children) a long-term arrangement that has mutual advantages and they can shape their lifestyle quite independently within the household. Others view this only as a stage in their family life course and look for ways to become independent, which has mainly financial barriers (Monostori and Murinkó 2015).

\subsection{Research questions and hypotheses}

The main objective of this paper is to analyse how people adjust their housing situation and place of residence to their changing family circumstances after partnership dissolution in Hungary. We formulate four research questions and four corresponding hypotheses regarding the housing consequences of divorce and separation in contemporary Hungary. 


\subsubsection{Cohabitation hypothesis}

The first research question concerns the relationship between partnership dissolution and residential change and the difference between previously married and cohabiting couples. While we know from previous studies that people who end their partnership are more likely to change residence than continuously partnered or single individuals, less is known about the difference between married and unmarried unions. Thus, the first question looks at whether separated or divorced people are more likely to move.

We expect that cohabiting ex-couples are more likely to change residence after splitting up than married couples. Our reasoning is based on observed differences between married and cohabiting couples: the latter ones are usually younger, they are in an earlier phase of their relationship, and they are less likely to be homeowners. They have probably invested less in their relationship and housing, and they are likely to give up their accommodation more easily. We assume that, after controlling for compositional differences like age, union duration, or parenthood status, the difference between cohabitation and marriage comes from their different probability to be homeowners.

\subsubsection{Status hypothesis}

The second question concerns the association between socioeconomic status (education and income) and the probability of moving among people who experience divorce or separation. Are people with more or fewer resources more likely to move after union dissolution? We expect that people with low socioeconomic status move more often after partnership dissolution than partners with higher income or education. We suppose that people with fewer resources need to move because they cannot afford to stay in the current house. Typically married couples live in their own homes, which they often sell in the case of a divorce and both former spouses move. In the case of joint home ownership, one partner can stay only if he or she buys the share of the other partner. In the case of renting, staying depends on the financial ability to maintain the flat by themselves after the partner left.

\subsubsection{Parental home hypotheses}

The third question is about the role of the parental household in residential relocations after divorce or separation. In Hungary the parental household can function both as a long-term living arrangement and as an important safety net. We separately examine the role of the parental household as both origin and destination. We expect that 
Murinkó: Housing consequences of divorce and separation in a 'super home ownership' regime

separation and divorce increase the risk of moving back to the parental home. Moreover, residential change is probably less likely for those who lived with their partner or spouse in the parental household before separation. In this case they simply continue living with the parents after union dissolution and the former partner leaves.

\subsubsection{Tenure hypothesis}

Last, we study where people move to. The most important aspect that we take into consideration is housing tenure. In line with previous research, we expect that people who experience partnership dissolution are more likely to rent, to live with their parents (as the child of the owner), or to choose other tenure forms. We also expect that living in owner-occupied dwellings is less common after divorce or separation than in intact relationships.

\section{Data and methods}

\subsection{The Hungarian Generations and Gender Survey}

We use data from the Hungarian Generations and Gender Survey (Turning Points of the Life Course Panel Survey; Vikat et al. 2007, Murinkó and Spéder 2016). The main focus of this large panel survey is fertility, partnerships, and aging, as well as related opinions and attitudes. The GGS focuses on family dynamics and relationships, with rich information on employment, education, and family-related attitudes as background variables, but detailed information on housing and residential mobility is missing. Still it is the best available longitudinal data source to study this issue in Hungary. The Hungarian GGS already has five waves: it started in $2001(\mathrm{n}=16,363)$, then the successive surveys took place in 2004, 2008, 2012, and 2016 (data from the last wave is not yet available for analysis). The original sample was representative of the Hungarian population aged 18-75 with regard to sex, age, and place of residence.

In this analysis we focus on change during the four-year period between waves 3 and 4 (i.e., between 2008 and 2012). We chose the last two available waves for the analysis so that the most recent trends can be investigated. Additionally, information on residential change is only available in wave $4 .{ }^{2}$ Our subsample includes respondents

\footnotetext{
${ }^{2}$ Even though the respondents' official address and the address where they were interviewed are available for each wave, they are not necessarily where they actually live. People who live in private rental or in a temporary accommodation are usually not registered there. Consequently, official and interview addresses would not provide reliable information to decide if respondents moved between survey waves or not.
} 
who were aged $25-59$ in wave $3(\mathrm{n}=5,408)$. The youngest respondents were already aged 25 by wave 3 , and we set an upper age limit because very few respondents divorced or separated above age 59. We exclude respondents who became widowed between waves 3 and $4(n=81)$ and who had no relationship in wave 3 but experienced a divorce or separation by wave $4(\mathrm{n}=61)$. Contrary to most studies with similar research aims, we do not exclude respondents who live with their parent(s). This phenomenon is much more frequent in Hungary than in Western and Northern Europe, even among people in their 30s and 40s (Iacovou and Skew 2011), thus excluding them would limit our understanding of the issue.

\subsection{Variables}

For the first set of analysis, our main variable of interest is change of residence between waves 3 and 4 . There was a direct question about residential change between waves, ${ }^{3}$ and $17 \%$ of our subsample reported that they moved between 2008 and $2012 .{ }^{4}$

In the second set of analysis, the main variable of interest is the housing tenure of the destination dwelling. A detailed tenure status variable is only available for wave 4 . It differentiates between owners; owner's partners, spouses, children and other relatives; people who rent a municipal dwelling, their spouses, partners, and other relatives (public rent); people who rent a whole apartment at the private market, who rent only part of an apartment, who rent only a room, or who share a room with others (private rent); people who live in housing provided by their employers or the employers of their partners, spouses, or other relatives; and rent-free living and other types of living arrangements. Several categories have very low number of cases, so we use the following tenure status variable in the analysis: owner, owner's partner or spouse, owner's child, owner's other relative, public rent, private rent, and other. We simplify this variable even further when estimating multinomial logistic regression models: we differentiate between (1) owner (owner, owner's partner/spouse, owner's other relative), (2) parental household (owner's child), and (3) renting (private or public) and other housing tenure.

In the third set of analysis, we focus on coresidence with parents. We distinguish between respondents who lived together with one or both biological parents in wave 3 and 4 . We also study whether the respondent moved back to the parental household between waves 3 and 4 .

\footnotetext{
${ }^{3}$ The question was as follows: "Have you moved since 2008?" Yes/No.

${ }^{4}$ The GGS does not follow former household members and does not survey couples, thus we do not know whether the former partner moved or not.
} 
Murinkó: Housing consequences of divorce and separation in a 'super home ownership' regime

In all models, the main independent variable is change in partnership status between waves 3 and 4 (see Table 1). Based on the full partnership histories available in the GGS, we distinguish five categories, similarly to Feijten and van Ham (2007):

1. Steady single: respondents who were single ${ }^{5}$ in both waves and had no unions in between.

2. Steady relationship: people who were in the same union in both waves, and no divorce, separation, widowhood, or repartnering happened in between. ${ }^{6}$

3. New relationship: respondents who were single in wave 3 and started a new cohabiting union or marriage by wave 4 .

4. Divorce/separation: people who experienced at least one divorce ${ }^{7}$ or separation between waves 3 and 4 and did not repartner.

5. Divorce/separation and repartnering: people who experienced at least one divorce or separation between waves 3 and 4 and found a new cohabiting partner or got married by wave 4 .

The group of 'divorce/separation and repartnering' is the smallest $(\mathrm{n}=115)$, and unfortunately we cannot analyse them in detail. Apart from basic descriptive statistics, this group is merged with the divorced/separated.

Table 1 shows that $7.6 \%$ of the sample experienced separation or divorce at least once between waves 3 and 4, and a quarter of this group also repartnered. Most individuals (86\%) did not experience any change in their partnership status during the analysed period: $63 \%$ lived in a steady relationship and $23 \%$ were steady single. Even in this relatively large sample $(n=5,408)$, the number of divorces and separations are relatively small.

We use several control variables in the regression models (Table 1). All variables that may have changed between survey waves (e.g., employment or parenthood status) refer to wave 3. Our independent variables include basic demographic information like sex, birth cohort, and parenthood status. The respondents whom we selected for analysis were born between 1948 and 1983, thus they were aged between 25 and 60 years in 2008 and between 29 and 64 in 2012.

Regarding parenthood status, we consider only biological children who were aged 18 or younger in wave 3 , no matter if they lived together with the respondent or not. A separate variable indicated if the respondent had a birth between waves 3 and 4 (about

\footnotetext{
${ }^{5}$ In this paper 'single' is defined as not having a spouse or cohabiting partner; people in a LAT relationship are treated as single. Both never-partnered and separated single respondents are included among 'singles.'

${ }^{6}$ Cohabiting couples who got married between waves 3 and 4 (12\% of nonmarried couples did so) are also included.

${ }^{7}$ Respondents who are still legally married but who no longer live with their spouse in a marital union (i.e., separated) are also included in this category.
} 
$11 \%$ did so), which is an important trigger for residential relocation as well as an indicator of having a small child in wave 4 (aged 4 years or younger). The birth of a child leads to a need for better and larger housing. Couples may adjust their housing situation to these demands in anticipation of childbirth (Kulu and Vikat 2007; Kulu and Steele 2013), but the likelihood of a residential relocation decreases after a child is born (Clark 2013).

We describe the partnership that the respondents had in wave 3 by its type (married, cohabiting, or no relationship) and its duration (1 year or less, 2-4, 5-10, 1020, and more than 20 years). We refer to the break-up of couples who cohabited in wave 3 as 'separation' and the break-up of couples who were married in wave 3 as 'divorce' (even if they are not yet legally divorced).

Socioeconomic background is measured using the highest level of education, employment status, and quintiles of net personal income in wave 3. We distinguish three educational categories: primary education (at most eight years of primary school), secondary education (general or vocational secondary school or vocational training school), and tertiary education (college or university degree). We differentiate between employed (full- and part-time employees, self-employed, and casual workers) and notemployed people (the unemployed, ${ }^{8}$ pensioners, disabled persons, people on parental leave, a few students and homemakers, and some people who did not work but did not tell any more details about their employment status). Income quintiles are calculated based on summary questions about the average total monthly net income of the respondent from all sources. If respondents did not want to give an exact number, they were offered categories to choose from. The middle values of the categories are used in the calculation of quintiles. We also include a variable on the type of settlement where respondents lived in wave 3 (the capital, city, town, or village). Housing quality is measured with two variables: the number of rooms and having garden or terrace.

\footnotetext{
${ }^{8}$ The unemployed is not treaded as a separate category here. After losing their job, former employees are entitled to unemployment benefit for no more than 36-90 days in Hungary. Afterwards they are officially not unemployed but belong to some other inactive categories.
} 
Murinkó: Housing consequences of divorce and separation in a 'super home ownership' regime

\section{Table 1: Descriptive statistics of the independent variables used in the analyses}

\begin{tabular}{|c|c|c|c|}
\hline Variable & Categories & Frequency & $\%$ \\
\hline \multirow{5}{*}{$\begin{array}{l}\text { Change in partnership status between } \\
\text { wave } 3 \text { and } 4\end{array}$} & Steady single & 1,250 & 23.1 \\
\hline & Steady relationship & 3,382 & 62.5 \\
\hline & New relationship & 362 & 6.7 \\
\hline & Divorce/separation & 299 & 5.5 \\
\hline & Divorce/separation and repartnering & 115 & 2.1 \\
\hline \multirow[t]{2}{*}{$\overline{\text { Sex }}$} & Male & 2,624 & 48.5 \\
\hline & Female & 2,784 & 51.5 \\
\hline \multirow[t]{4}{*}{ Birth cohort } & $1948-1959$ & 1,742 & 32.2 \\
\hline & $1960-1969$ & 1,350 & 25.0 \\
\hline & 1970-1979 & 1,744 & 32.3 \\
\hline & $1980-1983$ & 572 & 10.6 \\
\hline \multirow[t]{2}{*}{ Parenthood status in wave 3} & No children under 19 & 2,933 & 54.2 \\
\hline & Has child(ren) under 19 & 2,475 & 45.8 \\
\hline \multirow[t]{2}{*}{ Birth of a child between waves 3 and 4} & No & 4,832 & 89.4 \\
\hline & Yes & 576 & 10.6 \\
\hline \multirow[t]{3}{*}{ Union type in wave 3} & No relationship & 1,612 & 29.8 \\
\hline & Cohabitation & 799 & 14.8 \\
\hline & Marriage & 2,997 & 55.4 \\
\hline \multirow[t]{6}{*}{ Union duration in wave 3} & $\leq 1$ year & 87 & 1.6 \\
\hline & $2-4$ years & 377 & 7.0 \\
\hline & $5-10$ years & 705 & 13.0 \\
\hline & 10-20 years & 1,017 & 18.8 \\
\hline & $20+$ years & 1,582 & 29.3 \\
\hline & no relationship/no answer & 1,640 & 30.3 \\
\hline \multirow[t]{2}{*}{ Coresidence with parents in wave 3} & No & 4,506 & 83.3 \\
\hline & Yes & 902 & 16.7 \\
\hline \multirow[t]{3}{*}{ Level of education in wave 3} & Primary & 853 & 15.8 \\
\hline & Secondary & 3,301 & 61.0 \\
\hline & Tertiary & 1,254 & 23.2 \\
\hline \multirow[t]{2}{*}{ Employment status in wave 3} & Employed & 3,980 & 73.6 \\
\hline & Not employed & 1,428 & 26.4 \\
\hline \multirow[t]{6}{*}{ Net personal income quintiles in wave 3} & The lowest quintile & 909 & 16.8 \\
\hline & 2 & 801 & 14.8 \\
\hline & 3 & 965 & 17.8 \\
\hline & 4 & 1,058 & 19.6 \\
\hline & The highest quintile & 1,312 & 24.3 \\
\hline & No answer & 363 & 6.7 \\
\hline \multirow[t]{4}{*}{ Type of settlement in wave 3} & The capital (Budapest) & 872 & 16.1 \\
\hline & City & 1,140 & 21.1 \\
\hline & Town & 1,666 & 30.8 \\
\hline & Village & 1,730 & 32.0 \\
\hline \multirow[t]{2}{*}{ Has garden or terrace in wave 3} & No & 879 & 16.3 \\
\hline & Yes & 4,529 & 83.7 \\
\hline Number of rooms in wave 3 & & mean: 3.19 & \\
\hline Total & & 5,408 & 100.0 \\
\hline
\end{tabular}

Source: Author's calculations based on data from the Hungarian Generations and Gender Survey (Turning Points of the Life Course Panel Survey) waves 3 (2008) and 4 (2012), respondents aged 25-59 in wave $3(n=5,408)$. 


\subsection{Methods}

We use straightforward methods to study the relationship between partnership transitions and residential change: descriptive statistics with crosstabulation (weighted data) and logistic regression models on the probability of moving and tenure choice after union dissolution. In addition to reporting odds ratios, we use average marginal effects (AME) when presenting regression results. Using AMEs make the interpretation and the comparison of results easier, especially in the case of multinomial logistic regression models (see e.g., Mood 2010).

The first logistic regression model examines the odds of residential change in the whole sample (Figure 4 and Table A-1). The main variables of interest are a combined variable of change in partnership status between waves 3 and 4 and union type in wave 3 , as well as coresidence with parents. These two variables are included separately in Model 1. However, we expect that their effects are not independent from each other; therefore, we added an interaction between them in Model 2. The reference category of the interaction is respondents who have lived in a steady marital relationship and did not live with their parents in wave 3 . To control for composition effects and to see the impact of different factors on the probability of moving, both models include demographic background variables such as birth cohort, sex, parental status, and the birth of a child between waves. Characteristics of the union, variables of socioeconomic status, housing conditions, and place of residence are also added.

Second, we examine the probability of moving after divorce or separation. We estimate two logistic regression models: one for the divorced and one for the separated (Table 2). People who repartnered after union dissolution are included in the 'divorced/separated' category due to low number of cases. We can answer the cohabitation and the status hypotheses (and partly the parental home hypothesis) with the help of these models.

The last set of regression models is a multinomial logistic regression estimating the probability of living in owner-occupied accommodation, with parents, or in private rental or other tenure in wave 4 (Figure 5 and Table A-2). Here we added fewer control variables than in the previous models because of the low number of cases. The parental home and the tenure hypotheses can be answered using the results from these models. 


\section{Results}

\subsection{Who moves: residential change by change in partnership status}

First, we look at who moved between waves 3 and 4 . In total $17 \%$ of the respondents changed residence during the analysed four-year period. If we break down mobility rates by sex and change in partnership status, we see quite different patterns in different groups (Figure 1). Women and men living in a steady relationship or without a partner moved the least often (10-13\%). Respondents who experienced a change in their partnership status were more mobile: $46-47 \%$ of respondents who started a new relationship and $36-42 \%$ of respondents who divorced or separated moved. Residential change was the most common if someone experienced both union dissolution and repartnering ( $69 \%$ for women and $53 \%$ for men).

The frequency of residential mobility is similar for women and men $(16.3 \%$ vs. $17.3 \%)$. Single women, divorced or separated men, and divorced/separated and repartnered women move more often than their counterparts of the opposite sex (Figure 1).

Figure 1: Proportion of individuals experiencing residential mobility between waves 3 and 4 by sex and change in partnership status (\%)

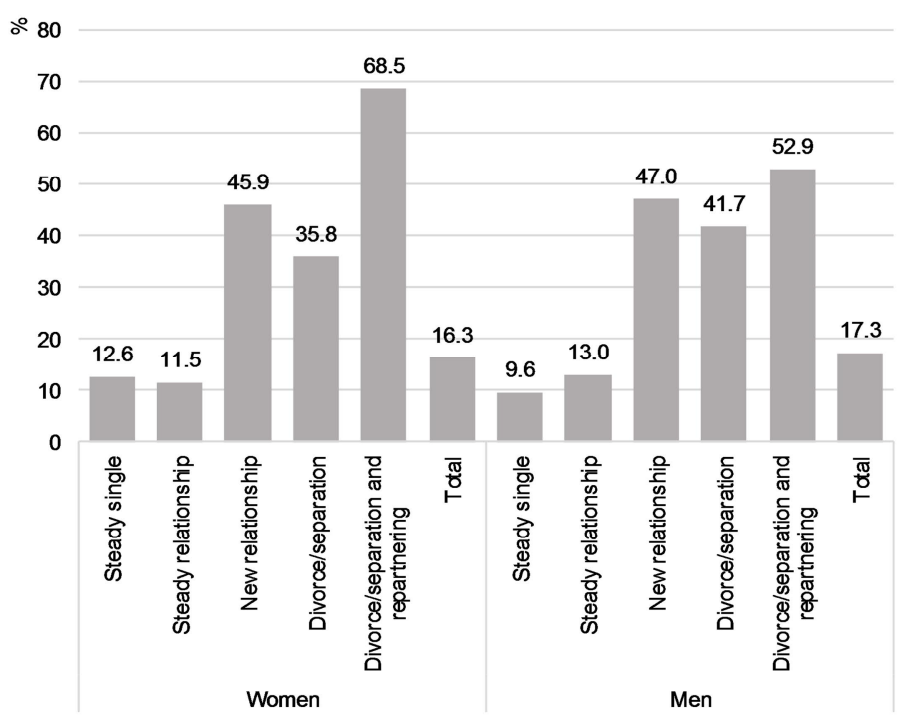

Source: Author's calculations based on data from the Hungarian Generations and Gender Survey (Turning Points of the Life Course Panel Survey) waves 3 (2008) and 4 (2012), respondents aged 25-59 in wave $3(n=5,408)$. 
Whether moving is more likely in cohabitation or marriage depends on how the partnership situation changed between survey waves (Figure 2). People in steady relationships move more often if they cohabited than if they were married in wave 3 . Moving is more common after divorce than after separation among men. However, there are no differences in the frequency of moving between previously married and cohabiting women. If union dissolution is followed by repartnering, formerly married men and women change residence more often than those who cohabited.

Figure 2: Proportion of individuals experiencing residential mobility between waves 3 and 4 by sex, change in partnership status and union type in wave $3(\%)$

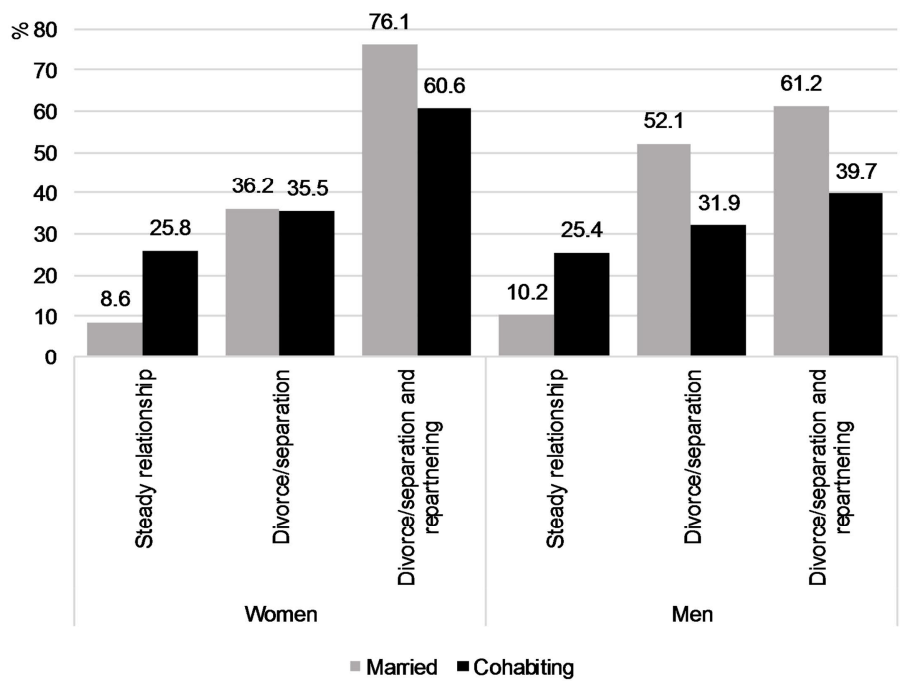

Note: Only among respondents who were partnered in wave 3.

Source: Author's calculations based on data from the Hungarian Generations and Gender Survey (Turning Points of the Life Course Panel Survey) waves 3 (2008) and 4 (2012), respondents aged 25-59 in wave 3 ( $n=5,408$ ).

Moving also depends on coresidence with parents (Figure 3). People who live in a steady relationship and who start a new union move more often if they lived with parents, while the opposite is true for people who get divorced or break up. 
Figure 3: Proportion of individuals experiencing residential mobility between waves 3 and 4 by sex, change in partnership status and coresidence with parent(s) in wave $3(\%)$

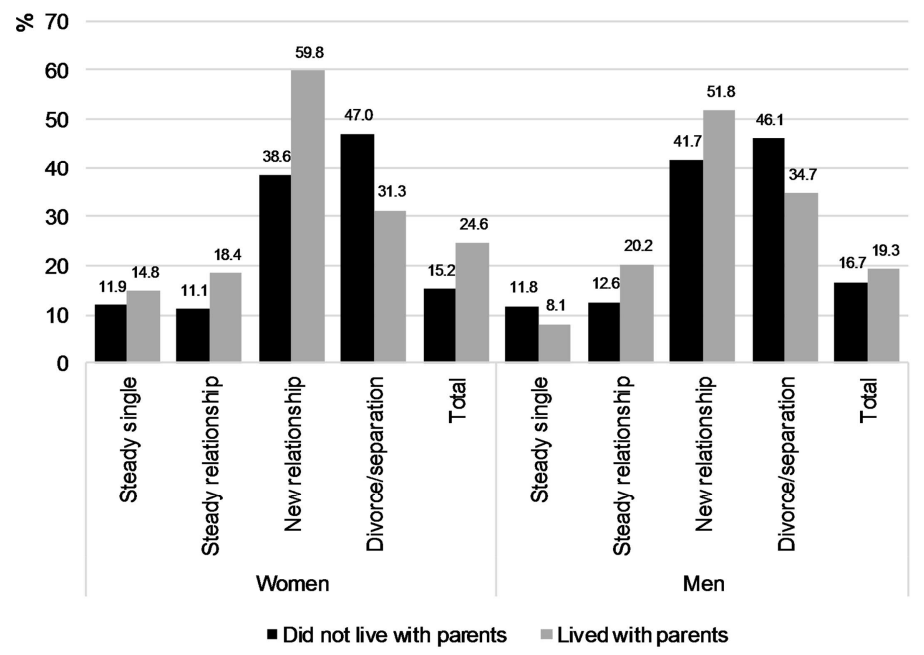

Note: The category 'divorce/separation' also includes respondents who repartnered after union dissolution.

Source: Author's calculations based on data from the Hungarian Generations and Gender Survey (Turning Points of the Life Course Panel Survey) waves 3 (2008) and 4 (2012), respondents aged 25-59 in wave 3 ( $n=5,408$ ).

Next, we perform logistic regression analyses to control for composition effects and to see the relationship between the probability of moving, partnership trajectories and various background factors. We present the regression estimates in Table A-1 in the Appendix. Based on the regression results of Model 2 in Table A-1, Figure 4 below shows average marginal effects for the interaction between our main variables of interest: change in partnership status, union type, and coresidence with parents. In Figure 4 the confidence intervals are often wide and overlapping, especially for categories with low number of cases. However, we can have a clearer picture of statistically significant differences if we also look at the main and the interaction effects separately in Table A-1. 
Figure 4: Average marginal effects and 95\% confidence intervals of residential change by change in partnership status, union type, and coresidence with parents

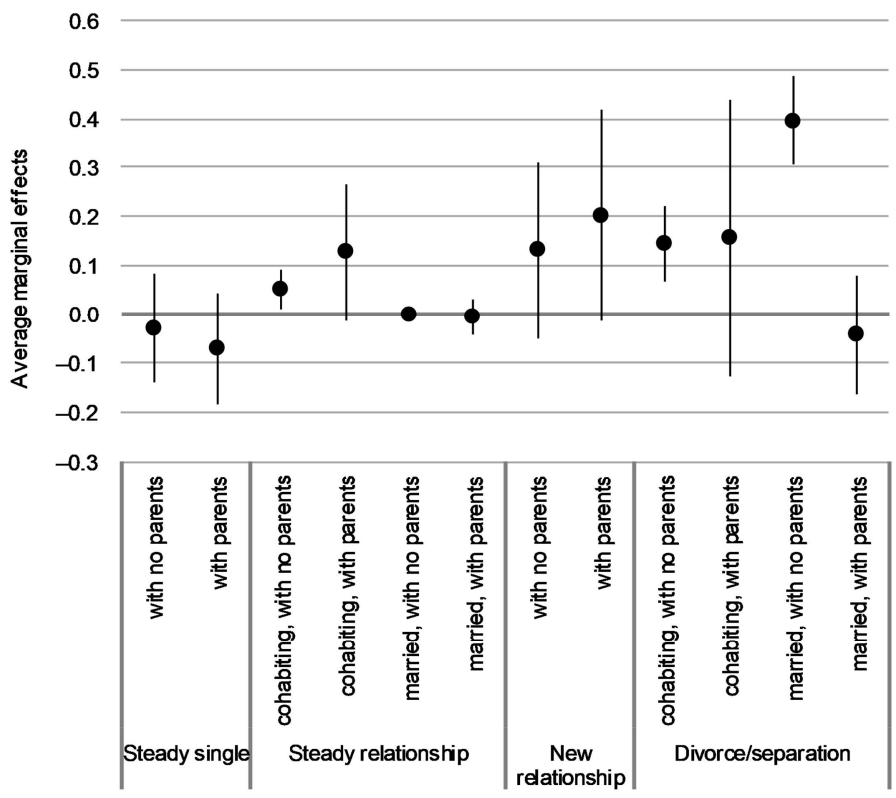

Note: The reference category is respondents living in a steady married relationship and not living with parents. Logistic regression analysis estimates. Sex, cohort, parenthood status, childbirth, union duration, education, employment status, income, type of settlement, number of rooms, and having garden/terrace are also controlled (see Model 2 in Table A-1).

Source: Author's calculations based on data from the Hungarian Generations and Gender Survey (Turning Points of the Life Course Panel Survey) waves 3 (2008) and 4 (2012), respondents aged 25-59 in wave $3(n=5,408)$.

Regression results confirm the descriptive finding that the probability of moving is higher after union formation and union dissolution than in an intact partnership, and steadily cohabiting couples are more likely to move than those who are steadily married (Figure 4 and Table A-1). Separation from an unmarried union increases the probability of moving by 0.15 , while divorce increases it by 0.37 (Model 1 in Table A-1). While living with parents is not related to moving when not interacted with any other variable (Model 1), the interaction term indicates that the relationship between residential change and divorce depends on parental coresidence (Model 2 in Table A-1). Formerly married respondents who lived with parents do not experience any change in their probability of moving after divorce, while divorce raises the probability of residential change by 0.4 if the couple lived separately from their parents. Parental coresidence does not make a difference for any other partnership groups. 
Murinkó: Housing consequences of divorce and separation in a 'super home ownership' regime

Regression analyses show some additional interesting results (Table A-1). Younger respondents and people whose relationship lasted for only a year or less by wave 3 are more likely to move than members of older cohorts and people in longer unions. Respondents who have children aged 18 years or younger are less likely to move than people with no minor children. The event of childbirth is related to moving, especially if it is the first child of the couple (results not shown). Better socioeconomic position (tertiary education and belonging to the highest income quintile) also increases the probability of moving. Village-dwellers, respondents who have fewer rooms or a garden or terrace also have lower probabilities of moving than people living in cities, in larger homes, and with no garden or terrace.

Next, we estimated separate regression models for the divorced and the separated in order to see how background factors are related to moving after union dissolution (Table 2). We find few factors that are related to residential change among divorced and separated respondents. Ending a relationship is an important life course event that triggers moving in itself, so there is not much room left for other explanatory factors. Results for the divorced and the separated differ from the ones discussed earlier regarding the whole sample (see Table A-1). In the whole sample the correlates of moving are probably driven by the largest group, the steadily partnered, and people who get divorced or break up move for different reasons.

If we look at separate models for separation and divorce, we see some differences between the two groups (Table 2). People who lived with parents are less likely to move after a divorce than people who did not live in the parental household with their former partners, while parental coresidence does not make a difference after a separation. The youngest respondents are more likely to move than members of older cohorts after the dissolution of a nonmarital union - probably they are more mobile and fewer of them were (joint) homeowners than respondents from older cohorts. Separation from a cohabiting union after twenty or more years is related to a low probability of moving, while we do not see the same relationship for long marriages.

The case of socioeconomic status is interesting (Table 2). The relationship of income with the probability of moving is U-shaped among formerly cohabiting and reversed U-shaped among formerly married respondents. In the case of divorce, not being employed is positively associated with the probability of moving, while tertiary education is negatively linked with moving propensity after separation. The opportunities and constraints for moving or staying are probably different for low- and high-income persons and for cohabiting and married ex-partners. We would need higher number of cases and more information on both ex-partners' socioeconomic status and tenure before and after union dissolution to disentangle the complex relationship between resources and moving. 
Table 2: Logistic regression estimates of the probability of a residential change among respondents who divorced and who separated from cohabitation

\begin{tabular}{|c|c|c|c|c|c|c|}
\hline & \multicolumn{3}{|l|}{ Divorce } & \multicolumn{3}{|c|}{ Separation from cohabitation } \\
\hline & OR & AME & $\mathbf{p}$ & OR & AME & $\mathbf{p}$ \\
\hline \multicolumn{7}{|l|}{ Living with parent(s) in wave 3} \\
\hline No & (ref.) & & & & & \\
\hline Yes & 0.04 & -0.49 & 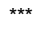 & 0.39 & -0.14 & \\
\hline \multicolumn{7}{|l|}{ Sex } \\
\hline Male & (ref.) & & & & & \\
\hline Female & 0.67 & -0.08 & & 1.68 & 0.08 & \\
\hline \multicolumn{7}{|l|}{ Birth cohort } \\
\hline 1948-1959 & (ref.) & & & & & \\
\hline 1960-1969 & 0.79 & -0.05 & & 1.36 & 0.05 & \\
\hline 1970-1979 & 1.06 & 0.01 & & 1.50 & 0.06 & \\
\hline $1980-1983$ & 2.48 & 0.18 & & 4.09 & 0.24 & $\dagger$ \\
\hline \multicolumn{7}{|l|}{ Parenthood status in wave 3} \\
\hline No children under 19 & (ref.) & & & & & \\
\hline Has child(ren) under 19 & 1.13 & 0.03 & & 2.13 & 0.12 & \\
\hline \multicolumn{7}{|c|}{ Birth of a child between waves 3 and 4} \\
\hline No & (ref.) & & & & & \\
\hline Yes & 0.63 & -0.10 & & 1.11 & 0.02 & \\
\hline \multicolumn{7}{|l|}{ Union duration in wave 3} \\
\hline$\leq 1$ year & 6.07 & 0.36 & & 0.56 & -0.10 & \\
\hline $2-4$ years & (ref.) & & & & & \\
\hline $5-10$ years & 1.77 & 0.12 & & 1.11 & 0.02 & \\
\hline $10-20$ years & 2.70 & 0.21 & & 0.40 & -0.16 & \\
\hline $20+$ years & 1.64 & 0.10 & & 0.02 & -0.42 & $\star * \star *$ \\
\hline \multicolumn{7}{|l|}{ Level of education in wave 3} \\
\hline Primary & 0.65 & -0.09 & & 0.36 & -0.16 & \\
\hline Secondary & (ref.) & & & & & \\
\hline Tertiary & 1.17 & 0.03 & & 0.39 & -0.15 & $\dagger$ \\
\hline \multicolumn{7}{|l|}{ Employment status in wave 3} \\
\hline Employed & (ref.) & & & & & \\
\hline Not employed & 3.12 & 0.22 & $\dagger$ & 1.10 & 0.02 & \\
\hline \multicolumn{7}{|c|}{ Personal income quintiles in wave 3} \\
\hline The lowest quintile & 0.18 & -0.35 & * & 5.12 & 0.30 & * \\
\hline 2 & 0.33 & -0.22 & & 0.79 & -0.04 & \\
\hline 3 & (ref.) & & & & & \\
\hline 4 & 0.67 & -0.08 & & 0.71 & -0.05 & \\
\hline The highest quintile & 0.34 & -0.22 & $\dagger$ & 5.54 & 0.31 & $* * *$ \\
\hline No answer & 0.24 & -0.29 & $\dagger$ & 0.35 & -0.14 & \\
\hline \multicolumn{7}{|l|}{ Type of settlement in wave 3} \\
\hline The capital (Budapest) & (ref.) & & & & & \\
\hline City & 0.80 & -0.05 & & 0.44 & -0.14 & \\
\hline Town & 0.52 & -0.14 & & 0.39 & -0.16 & \\
\hline Village & 0.72 & -0.07 & & 0.34 & -0.19 & \\
\hline \multicolumn{7}{|l|}{ Has garden/terrace in wave 3} \\
\hline No & (ref.) & & & & & \\
\hline Yes & 2.24 & 0.17 & $\dagger$ & 0.79 & -0.04 & \\
\hline Number of rooms in wave 3 & 1.01 & 0.001 & & 1.11 & 0.02 & \\
\hline Log likelihood & -134.6 & & & -108.2 & & \\
\hline Pseudo $\mathrm{R}^{2}$ & 0.129 & & & 0.257 & & \\
\hline $\mathrm{N}$ & 209 & & & 204 & & \\
\hline
\end{tabular}

Note: ${ }^{* * *} \mathrm{p}<0.001,{ }^{* *} \mathrm{p}<0.01,{ }^{*} \mathrm{p}<0.05$, $\dagger \mathrm{p}<0.1$. OR $=$ odds ratio, AME $=$ average marginal effect. The category 'divorce/separation' also includes respondents who repartnered after union dissolution.

Source: Author's calculations based on data from the Hungarian Generations and Gender Survey (Turning Points of the Life Course Panel Survey) waves 3 (2008) and 4 (2012), respondents aged 25-59 in wave 3 ( $n=5,408$ ). 
Murinkó: Housing consequences of divorce and separation in a 'super home ownership' regime

\subsection{Where people move to: Destination housing tenure by change in partnership status}

In the second part of the analysis, we examine where people moved to regarding the household composition and tenure status of their new place of residence. First, we briefly describe the differences in housing tenure and parental coresidence by change in partnership status.

While the great majority of the Hungarian population lives in owner-occupied dwellings, we find that owner occupation is less frequent among people who changed residence between survey waves $(72 \%$, see Table 3$)$ than in the whole sample $(91 \%$, not shown). Steadily single and steadily partnered people most often moved to a place of their own or a relative. Moving to the place of the partner or spouse was the most common in new relationships. As we have already seen, steady single and divorced people tend to move to the parents' home. Moving to the parental household is more common after divorce than separation and among men than women. Private rent and other solutions are also common among the divorced, the separated and the repartnered. Overall, alternative solutions become more important after a partnership transition, especially divorce or separation.

Table 3: Housing tenure in wave 4 by sex and change in partnership status among those who moved since wave 3 (\%)

\begin{tabular}{|c|c|c|c|c|c|c|c|c|c|}
\hline & \multicolumn{5}{|c|}{ Owner or owner's relative } & \multirow[b]{2}{*}{$\begin{array}{l}\text { Public } \\
\text { rent }\end{array}$} & \multirow[b]{2}{*}{$\begin{array}{l}\text { Private } \\
\text { rent }\end{array}$} & \multirow[b]{2}{*}{ Other } & \multirow[b]{2}{*}{ Total } \\
\hline & Total & Owner & $\begin{array}{l}\text { Owner's } \\
\text { partner/spouse }\end{array}$ & $\begin{array}{l}\text { Owner's } \\
\text { child }\end{array}$ & $\begin{array}{l}\text { Owner's other } \\
\text { relative }\end{array}$ & & & & \\
\hline \multicolumn{10}{|l|}{ Women } \\
\hline Steady single & 74.4 & 46.8 & - & 18.0 & 9.6 & 1.7 & 17.9 & 6.0 & 100.0 \\
\hline Steady relationship & 75.5 & 53.2 & 12.8 & 3.9 & 5.6 & 6.2 & 13.6 & 4.8 & 100.0 \\
\hline New relationship & 80.3 & 42.2 & 30.0 & 6.3 & 1.8 & 2.3 & 15.2 & 2.1 & 100.0 \\
\hline Divorce, separation & 53.5 & 29.7 & - & 16.6 & 7.2 & 5.9 & 23.0 & 17.6 & 100.0 \\
\hline From cohabitation & 56.5 & 32.4 & - & 10.0 & 14.1 & 3.9 & 15.3 & 24.3 & 100.0 \\
\hline From marriage & 50.4 & 26.9 & - & 23.5 & 0.0 & 8.0 & 31.0 & 10.6 & 100.0 \\
\hline Divorce/separation and repartnering & 54.3 & 14.7 & 24.1 & 13.6 & 1.9 & 1.7 & 36.7 & 7.3 & 100.0 \\
\hline Total & 71.6 & 43.8 & 12.8 & 9.4 & 5.6 & 4.3 & 17.9 & 6.3 & 100.0 \\
\hline \multicolumn{10}{|l|}{ Men } \\
\hline Steady single & 78.7 & 52.1 & - & 24.6 & 2.0 & - & 18.1 & 3.2 & 100.0 \\
\hline Steady relationship & 79.0 & 64.0 & 4.9 & 4.3 & 5.8 & 5.9 & 13.1 & 2.1 & 100.0 \\
\hline New relationship & 70.5 & 35.6 & 20.5 & 7.8 & 6.6 & 5.2 & 19.4 & 4.9 & 100.0 \\
\hline Divorce, separation & 54.1 & 25.5 & - & 25.0 & 3.6 & 0.0 & 42.3 & 3.6 & 100.0 \\
\hline From cohabitation & 45.9 & 27.5 & - & 12.9 & 5.5 & 0.0 & 54.1 & 0.0 & 100.0 \\
\hline From marriage & 59.5 & 24.2 & - & 32.8 & 2.5 & 0.0 & 34.7 & 5.9 & 100.0 \\
\hline Divorce/separation and repartnering & 60.7 & 34.6 & 22.8 & 3.3 & 0.0 & 4.1 & 13.5 & 21.8 & 100.0 \\
\hline Total & 72.7 & 49.6 & 8.0 & 10.2 & 4.9 & 4.1 & 18.9 & 4.2 & 100.0 \\
\hline Total & 72.1 & 46.7 & 10.4 & 9.8 & 5.2 & 4.2 & 18.4 & 5.3 & 100.0 \\
\hline
\end{tabular}

Note: '-' indicates an empty category.

Source: Author's calculations based on data from the Hungarian Generations and Gender Survey (Turning Points of the Life Course Panel Survey) waves 3 (2008) and 4 (2012), respondents aged 25-59 in wave $3(n=5,408)$. 
Next, we analyse the role of the parental home for people with different partnership trajectories. If we look at the descriptive results regarding differences by change in partnership status, we can see that living in the parental household is the most common among unpartnered people, especially men (the majority of steady single men live with their parents) (Table 4). Living with parents is also quite common in the "new relationship' group. Returning to the parental home is common after union dissolution ( $30 \%$ of men and $18 \%$ of women did so), especially after divorce. ${ }^{9}$ This is not the case if repartnering followed union dissolution: only few new couples live with the respondents' parents. The financial crisis may explain the relatively high rate of returning to the parental household among steady single men (on average single men have lower education and are more likely to live in smaller settlements with more limited employment opportunities than single women). It seems that union dissolution is often followed by returning to the parental household, while union formation is a way out of it.

Table 4: Living with parent(s) in the whole sample and moving back to the parental household among people who moved between waves 3 and 4 by sex and change in partnership status (\%)

\begin{tabular}{lrrr}
\hline & \multicolumn{2}{c}{ Living with parent(s) in the whole sample } & Living with parent(s) \\
\cline { 2 - 3 } & In wave 3 & In wave 4 & \\
Women & & & 6.6 \\
Steady single & 23.0 & 20.3 & 3.3 \\
Steady relationship & 5.8 & 4.2 & 1.1 \\
New relationship & 34.5 & 10.3 & 17.5 \\
Divorce/separation & 11.5 & 13.6 & 9.1 \\
$\quad$ From cohabitation & 11.2 & 10.7 & 26.2 \\
$\quad$ From marriage & 11.9 & 16.7 & 2.9 \\
Divorce/separation and repartnering & 11.3 & 5.0 & 5.2 \\
Total & 12.4 & 9.0 & 14.5 \\
\hline Men & & & 1.6 \\
Steady single & 60.3 & 52.1 & 0.0 \\
Steady relationship & 5.5 & 3.6 & 30.0 \\
New relationship & 52.5 & 10.6 & 26.0 \\
Divorce/separation & 15.7 & 31.4 & 32.6 \\
$\quad$ From cohabitation & 24.0 & 35.5 & 0.0 \\
$\quad$ From marriage & 6.9 & 27.1 & 6.6 \\
Divorce/separation and repartnering & 2.3 & 2.3 & 5.9 \\
Total & 21.5 & 16.3 & \\
\hline Total & 16.7 & 12.5 & \\
\hline
\end{tabular}

Source: Author's calculations based on data from the Hungarian Generations and Gender Survey (Turning Points of the Life Course Panel Survey) waves 3 (2008) and 4 (2012), respondents aged 25-59 in wave $3(n=5,408)$.

${ }^{9}$ The proportion of divorced or separated people who returned to the parental home for some time is probably higher than the figures presented in Table 4, because we do not have information on temporary coresidence between adult children and their parents if it did not last until wave 4 . 
Last, we estimate a multinomial logistic regression model to compare the probabilities of moving (a) to an owner-occupied dwelling (the category includes owners, owners' partners/spouses and owners' other relatives), (b) to the parental household, or (c) to private rental or other housing tenure. We look at the relationship between destination housing tenure and partnership change separately for men and women (with the help of an interaction between them) because descriptive results show that housing tenure and parental coresidence differ among men and women (see Table 3 and 4). The regression estimates are presented in Table A-2 in the Appendix. Based on these regression results, Figure 5 below shows average marginal effects for change in partnership status and union type by sex.

Results of the multinomial logistic regression show that the probability of home ownership after a move is lower after union dissolution than in an intact relationship, and it equally applies to both the previously married and the formerly cohabiting (Figure 5). This negative relationship is strong for men and on the verge of statistical significance for women. Steadily cohabiting men are also less likely to move to owner occupation than their married counterparts.

If men change residence, they are more likely to return to the parental household than women, especially following divorce or separation (as shown by the negative AMEs for women and for the interaction between divorce/separation and women in Table A-2). Among women, divorce or separation is unrelated to the probability of returning to the parental home. Partnership dissolution increases the probability that someone moves to private rental and other tenure forms about equally among women and men and about equally following the dissolution of a marriage and a cohabiting relationship.

Regarding other factors, we can see that low level of education is positively and high income is negatively associated with the probability of moving back to the parental home (Table A-2). People who had a childbirth between wave 3 and wave 4 were less likely to move in with their parents and more likely to move to owneroccupied housing. Parents and people of a very short union often choose private rental or other tenure forms and do not become homeowners. 
Figure 5: Average marginal effects and $95 \%$ confidence intervals of the probability of moving to different tenure types by sex and change in partnership status among people who moved between waves 3 and 4

a) Owner

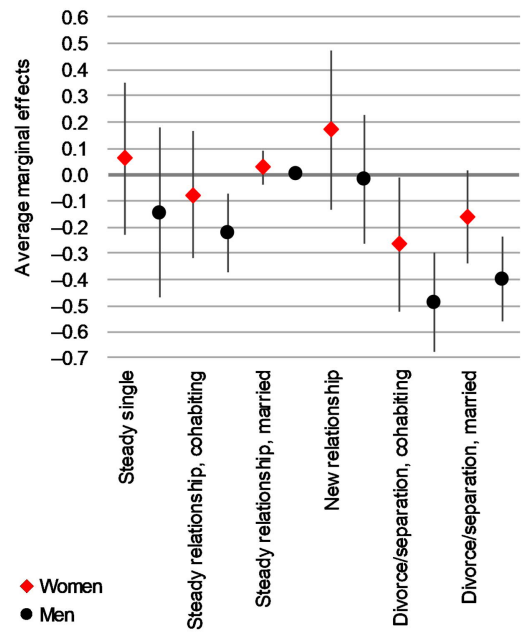

c) Private rental or other

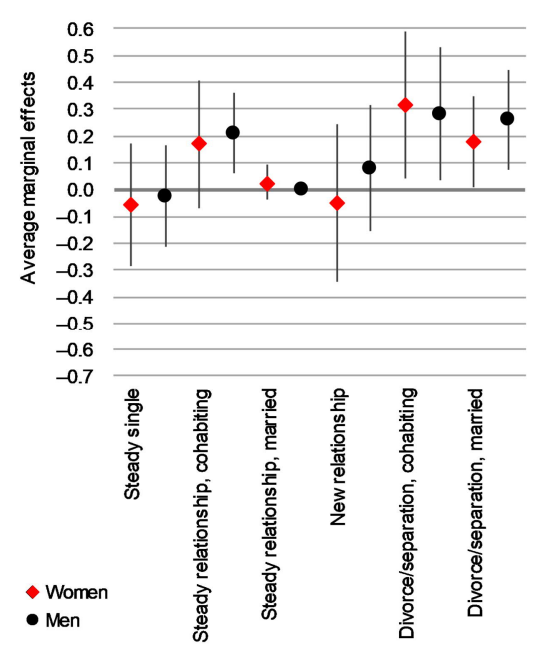

b) Parental household

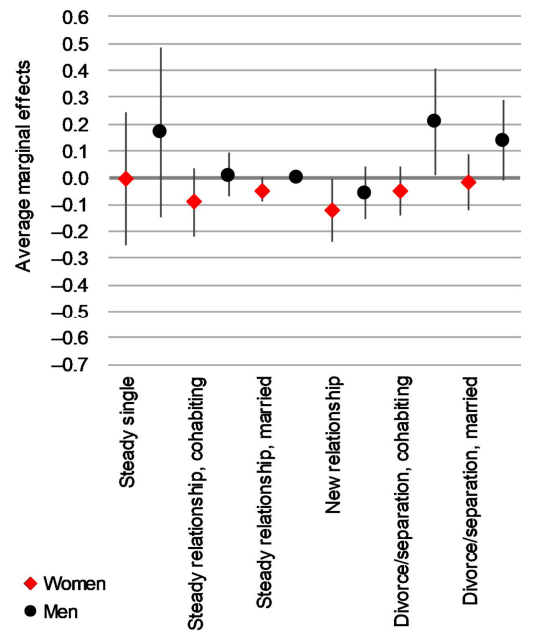

Notes: Multinomial logistic regression analysis estimates. The reference category is men living in a steady married relationship. Cohort, parenthood status, childbirth, union duration, education, and income are controlled (see Table A-2).

Source: Author's calculations based on data from the Hungarian Generations and Gender Survey (Turning Points of the Life Course Panel Survey) waves 3 (2008) and 4 (2012), respondents aged 25-59 in wave $3(n=5,408)$. 


\section{Discussion and conclusions}

This paper examined some aspects of the housing consequences of partnership dissolution in Hungary between 2008 and 2012 using data from the Hungarian Generations and Gender Survey.

The empirical analysis showed that moving is more likely after both union formation and union dissolution, and if both partnership events take place within the examined four-year interval, people are even more likely to move. Steady single respondents and people in a steady relationship are the least likely to change residence.

We expected that the probability of moving was higher after separation from cohabitation than after divorce (cohabitation hypothesis). Contrary to our hypothesis, we found that moving is more common after divorce than after separation (with the exception that divorce does not motivate moving if the couple lived with parents prior to separation). How can we explain the higher probability of moving after divorce than separation? Marriage and cohabitation often involve different tenure choices. Cohabiting couples, who are often at an earlier stage of their relationship than those who are married, are less likely to be homeowners and more likely to rent or live at their partners' (or the partner's parents') place. Married couples are more likely to be homeowners than cohabiting couples. Moreover, it is common that spouses are joint owners of the property. Therefore, they often have to sell the joint home and move after divorce because neither of them can afford to maintain (or buy) it by themselves. Another possibility is if their house has a relatively high market value, spouses sell the common home after divorce and both buy an own (smaller) house for themselves. This might explain why previously married people are more likely to move following divorce than those who were previously cohabiting.

The status hypothesis stated that low socioeconomic status increases the probability of moving among the divorced and the separated. Our results partly confirm this hypothesis but also prove that the situation is more complex and we cannot fully understand it with the present data. We found a U-shaped relationship between personal income and moving after separation and an inverse U-shaped association after divorce. Nevertheless, the probability of residential change seems to be only weakly related to socioeconomic status among the divorced and the separated. Experiencing a partnership event - either starting or ending a union - often encourages moving in itself, regardless of socioeconomic status.

Regarding the role of the parental household, we formulated two parental home hypotheses. First, we expected that moving back to the parental household is more likely after separation or divorce than among people in an intact relationship or steady single respondents. Second, we argued that residential change after union dissolution is less likely if the couple lived with the parents of one of the former partners. We found 
support for the first hypothesis only among men, and for the second hypothesis only among the previously married. We found that moving back to the parental household is indeed common after union dissolution, especially among men. Family solidarity - in the form of coresidence between adult children and their parent(s) - plays an important role in solving the housing crisis after union dissolution, and the parental home functions as a 'safety net.' Among steadily single men, the high rate of returning to the parental household during the years of economic crisis also points in this direction. Union dissolution increases the probability of returning to the parental home among men but not among women. This may be because the costs and benefits of living in the parental household differ for adult daughters and sons. Women do more housework, their behaviour is more closely monitored, and they enjoy less freedom in the parental home than men (Goldscheider and DaVanzo 1985; White 1994).

Living with parents as a couple probably has different meanings for the married and the cohabiting. It may be a temporary solution for people who cannot (yet) afford moving if the relationship is in its initial phase. If this is the case, moving is part of the process of the transition to adulthood and becoming independent from one's parents. In contrast, coresidence with parents may also be a long-term arrangement both for single and partnered people in such cases when the parental home is spacious, when there are financial constraints of moving, or when either the adult child or the parent(s) need assistance. In this scenario, union dissolution does not increase the risk of moving - the adult child continues to live with the parents - as we saw in the regression results.

Regarding the destination of moves, we argued that private rental and other tenure forms are more common than owner-occupation after separation or divorce. The tenure hypothesis is confirmed: after union dissolution, private rent, living rent-free, and other solutions are more common than homeownership.

There are many aspects of residential change and housing that we do not consider in this paper, such as the quality and size of the new accommodation, or the distance and the direction of a move. These are also important elements but we would like to study the basics before moving on to more detailed analyses of the relationship between partnership events and housing. The data we use also poses some limitations for the analysis. There is no information on tenure status in wave 3 . The dates of moving are unfortunately not available, consequently we cannot distinguish between moves due to separation and moves of separated individuals (as, for example, Mikolai and Kulu 2018). We do not know about multiple 'adjustment' moves, and other elements of the housing history are also missing. Consequently, we probably underestimate the probability of renting, living with parents, or choosing some other 'unconventional' living arrangement after divorce or separation if they were only short-term and temporary solutions. Moreover, attrition is higher among respondents who have experienced divorce/separation and who have moved (Makay 2016), probably resulting 
in some underestimation of the probability of partnership dissolution and residential change.

Understanding the interplay between partnership processes and the unique characteristics of the Hungarian housing regime - the high rate of homeownership and the common coresidence of adult children and their parents - is important in light of recent demographic developments such as the increasing fragility of partnerships. If homeownership is the only viable long-term housing solution and a home is often the only and hard-earned property of a family, giving it up or losing it may have serious consequences for individuals' financial and physical well-being. Moving may of course mean a fresh start and a new opportunity after partnership dissolution, but residential instability may also be a source of vulnerability (chronic stress, loss of social support, low housing quality, poverty, or even homelessness) (Kocsis 2004). The lack of housing opportunities not only limits spatial and, eventually, social mobility, but it may also restrict the formation of new households. One such consequence is the relatively high ratio of adult children still (or again) living with their parents, which puts a strain on family solidarity. Moreover, not only divorce affects housing tenure, but the relationship may also work the other way around: homeownership may deter or make divorce more difficult (Grinstein-Weiss et al. 2014)

\section{Acknowledgements}

An earlier version of the paper was presented at the International Research and Policy Symposium on Family Changes and Housing Transitions in the Life Course in St. Andrews, UK (18-19 May 2017). The author thanks Julia Mikolai, the editors of the Demographic Research special edition, and the two anonymous reviewers for their helpful comments on the manuscript. 


\section{References}

Aassve, A., Arpino, B., and Billari, F.C. (2013). Age norms on leaving home: Multilevel evidence from the European Social Survey. Environment and Planning A: Economy and Space 45(2): 383-401. doi:10.1068/a4563.

Aassve, A., Cottini, E., and Vitali, A. (2013). Youth prospects in a time of economic recession. Demographic Research 29(36): 949-962. doi:10.4054/DemRes.2013. 29.36 .

Albertini, M., Gähler, M., and Härkönen, J. (2018). Moving back to 'mamma'? Divorce, intergenerational coresidence, and latent family solidarity in Sweden. Population, Space and Place 24(6): e2142. doi:10.1002/psp.2142.

Andreß, H.-J. and Hummelsheim, D. (2009). When marriage ends: Economic and social consequences of partnership dissolution. Cheltenham: Edward Elgar. doi:10.4337/9781848447202.

Bálint, L. and Gödri, I. (2015). Internal migration. In: Monostori, J., Öri, P., and Spéder, Zs. (eds.). Demographic portrait of Hungary 2015: Report on the conditions of the Hungarian population. Budapest: Hungarian Demographic Research Institute: 169-184.

Booth, A. and Amato, P. (1993). Divorce, residential change, and stress. Journal of Divorce and Remarriage 18(1-2): 205-214. doi:10.1300/J087v18n01_10.

Carlson, E. and Klinger, A. (1987). Partners in life: Unmarried couples in Hungary. European Journal of Population 3(1): 85-59. doi:10.1007/BF01797093.

Clark, W.A.V. (2013). Life course events and residential change: Unpacking age effects on the probability of moving. Journal of Population Research 30(4): 319-334. doi:10.1007/s12546-013-9116-y.

Cooke, T.J., Mulder, C.H., and Thomas, M. (2016). Union dissolution and migration. Demographic Research 34(26): 741-760. doi:10.4054/DemRes.2016.34.26.

Coulter, R., van Ham, M., and Findlay, A.M. (2016). Re-thinking residential mobility: Linking lives through time and space. Progress in Human Geography 40(3): 352-374. doi:10.1177/0309132515575417.

Das, M., de Valk, H., and Merz, E.-M. (2017). Mothers' mobility after separation: Do grandmothers matter? Population, Space and Place 23(2): e2010. doi:10.1002/ psp.2010. 
Murinkó: Housing consequences of divorce and separation in a 'super home ownership' regime

Dewilde, C. (2009). Divorce and housing: A European comparison of the housing consequences for men and women. In: Andreß, H.-J. and Hummelsheim, D. (eds.). When marriage ends: Economic and social consequences of partnership dissolution. Cheltenham: Edward Elgar: 263-285. doi:10.4337/9781848447202. 00019 .

Dewilde, C. and Stier, H. (2014). Homeownership later in life: Does divorce matter? Advances in Life Course Research 20: 28-42. doi:10.1016/j.alcr.2014.01.002.

Eurostat (2016). Housing conditions [electronic resource]. Luxembourg: Eurostat. https://ec.europa.eu/eurostat/statistics-explained/index.php?title=Archive: Housing_conditions.

Feijten, P. (2005). Union dissolution, unemployment and moving out of home ownership. European Sociological Review 21(1): 59-71. doi:10.1093/esr/jci004.

Feijten, P. and van Ham, M. (2007). Residential mobility and migration of the divorced and separated. Demographic Research 17(21): 623-654. doi:10.4054/DemRes. 2007.17.21.

Feijten, P. and van Ham, M. (2010). The impact of splitting up and divorce on housing careers in the UK. Housing Studies 25(4): 483-507. doi:10.1080/026730310 03711477 .

Feijten, P. and van Ham, M. (2013). The consequences of divorce and splitting up for spatial mobility in the UK. Comparative Population Studies 38(2): 405-432.

Földházi, E. (2005). Az elváltak lakáskörülményei [Housing conditions of the divorced]. Demográfia 48(4): 375-414.

Földházi, E. (2015). Divorce and separation. In: Monostori, J., Öri, P., and Spéder, Zs. (eds.). Demographic portrait of Hungary 2015: Report on the conditions of the Hungarian population. Budapest: Hungarian Demographic Research Institute: 27-39.

Goldscheider, F.K. and DaVanzo, J. (1985). Living arrangements and the transition to adulthood. Demography 22(4): 545-563. doi:10.2307/2061587.

Grinstein-Weiss, M., Manturuk, K.R., Guo, S., Charles, P., and Key, C. (2014). The impact of homeownership on marriage and divorce: Evidence from propensity score matching. Social Work Research 38(2): 73-90. doi:10.1093/swr/svu016.

Grundy, E. (2000). Co-residence of mid-life children with their elderly parents in England and Wales: Changes between 1981 and 1991. Population Studies 54(2): 193-206. doi:10.1080/713779085. 
Hegedüs, J. and Horváth, V. (2018). Hungary: The growing role of a hidden sector. In: Hegedüs, J., Lux, M., and Horváth, V. (eds.). Private rental housing in transition countries: An alternative to owner occupation? London: Palgrave Macmillan: 235-260. doi:10.1057/978-1-137-50710-5_10.

Hegedüs, J. and Teller, N. (2006). Managing risks in the new housing regimes of the transition countries: The case of Hungary. In: Doling, J. and Elsinga, M. (eds.). Home ownership: Getting in, getting from, getting out: Part II. Amsterdam: IOS Press: $175-200$.

Hegedüs, J. and Teller, N. (2007). Hungary: Escape into home ownership. In: Elsinga, M., De Decker, P., Teller, N., and Toussaint, J. (eds.). Home ownership beyond asset and security: Perceptions of housing related security and insecurity in eight European countries. Amsterdam: IOS Press: 133-171.

Hegedüs, J., Horváth, V., and Tosics, N. (2014). Economic and legal conflicts between landlords and tenants in the Hungarian private rental sector. International Journal of Housing Policy 14(2): 141-163. doi:10.1080/14616718.2014.908571.

Hiekel, N., Liefbroer, A.C., and Poortman, A.-R. (2014). Understanding diversity in the meaning of cohabitation across Europe. European Journal of Population 30(4): 391-410. doi:10.1007/s10680-014-9321-1.

Iacovou, M. and Skew, A.J. (2011). Household composition across the new Europe: Where do the new Member States fit in? Demographic Research 25(14): 465490. doi:10.4054/DemRes.2011.25.14.

Kocsis, J.B. (2004). The housing poor in Budapest, Hungary: Situation and perspectives. In: Fearn, J. (ed.). Too poor to move, too poor to stay: A report on housing in the Czech Republic, Hungary and Serbia. Budapest: Open Society Institute: $67-95$.

KSH (2013). 2011. évi népszámlálás: 6. A lakások és lakóik [Population census 2011: 6. Dwellings and their occupants]. Budapest: Központi Statisztikai Hivatal.

KSH (2016). Miben élünk? A 2015. évi lakásfelmérés föbb eredményei [Where do we live? Main results of the Housing Survey 2015]. Budapest: Központi Statisztikai Hivatal.

KSH (2017). Mikrocenzus 2016: Demográfiai adatok [Microcensus 2016: Demographic data]. Budapest: Központi Statisztikai Hivatal. 
Murinkó: Housing consequences of divorce and separation in a 'super home ownership' regime

Kulu, H. and Steele, F. (2013). Interrelationships between childbearing and housing transitions in the family life course. Demography 50(5): 1687-1714. doi:10.10 07/s13524-013-0216-2.

Kulu, H. and Vikat, A. (2007). Fertility differences by housing type: The effect of housing conditions or of selective moves? Demographic Research 17(26): 775802. doi:10.4054/DemRes.2007.17.26.

Leopold, T. (2018). Gender differences in the consequences of divorce: A study of multiple outcomes. Demography 55(3): 769-797. doi:10.1007/s13524-018-06 67-6.

Makay, Z. (2016). Lemorzsolódás az adatfelvétel négy hulláma során [Attrition during the four survey waves]. In: Murinkó, L. and Spéder, Zs. (eds.). Felhasználói kézikönyv az Életünk fordulópontjai panelkutatás 1-4. hullámához [Users' guide for waves 1-4 of the Turning Points of the Life Course panel survey]. Budapest: KSH Népességtudományi Kutatóintézet (NKI Kutatási jelentések 97): 53-63.

Mikolai, J. and Kulu, H. (2018). Divorce, separation, and housing changes: A multiprocess analysis of longitudinal data from England and Wales. Demography 55(1): 83-106. doi:10.1007/s13524-017-0640-9.

Monostori, J. and Murinkó, L. (2015). Family and household structure. In: Monostori, J., Öri, P., and Spéder, Zs. (eds.). Demographic portrait of Hungary 2015: Report on the conditions of the Hungarian population. Budapest: Hungarian Demographic Research Institute: 151-168.

Mood, C. (2010). Logistic regression: Why we cannot do what we think we can do, and what we can do about it. European Sociological Review 26(1): 67-82. doi:10.10 93/esr/jcp006.

Morris, T. (2017). Examining the influence of major life events as drivers of residential mobility and neighbourhood transitions. Demographic Research 36(35): 10151038. doi:10.4054/DemRes.2017.36.35.

Mulder, C.H. and Hooimeijer, P. (1999). Residential relocations in the life course. In: van Wissen, L.J.G. and Dykstra, P.A. (eds.). Population issues: An interdisciplinary focus. New York: Kluwer Academic/Plenum Publishers: 159186. doi:10.1007/978-94-011-4389-9_6.

Mulder, C.H. and Malmberg, G. (2011). Moving related to separation: Who moves and to what distance. Environment and Planning A: Economy and Space 43(11): 2589-2607. doi:10.1068/a43609. 
Mulder, C.H. and Wagner, M. (2010). Union dissolution and mobility: Who moves from the family home after separation? Journal of Marriage and Family 72(5): 1263-1273. doi:10.1111/j.1741-3737.2010.00763.x.

Mulder, C.H. and Wagner, M. (2012). Moving after separation: The role of locationspecific capital. Housing Studies 27(6): 839-852. doi:10.1080/02673037.20 12.651109 .

Mulder, C.H., Hengel, B., Latten, J., and Das, M. (2012). Relative resources and moving from the joint home around divorce. Journal of Housing and the Built Environment 27(2): 153-168. doi:10.1007/s10901-011-9250-9.

Murinkó, L. (2013). Első elköltözés a szülői házból Magyarországon: A szülői ház elhagyásának időzítése, párkapcsolati környezete és családi háttér szerinti különbségei [Leaving the parental home in Hungary: Timing, partnership context and differences by family background]. Budapest: KSH Népességtudományi Kutatóintézet (NKI Kutatási jelentések 94).

Murinkó, L. and Spéder, Zs. (2015). Marriage and cohabitation. In: Monostori, J., Öri, P., and Spéder, Zs. (eds.). Demographic portrait of Hungary 2015: Report on the conditions of the Hungarian population. Budapest: Hungarian Demographic Research Institute: 9-26.

Murinkó, L. and Spéder, Zs. (2016). Felhasználói kézikönyv az Életünk fordulópontjai panelkutatás 1-4. hullámához [Users' guide for waves 1-4 of the Turning Points of the Life Course panel survey]. Budapest: KSH Népességtudományi Kutatóintézet (NKI Kutatási jelentések 97).

Oláh, L.Sz. (2001). Gender and family stability: Dissolution of the first parental union in Sweden and Hungary. Demographic Research 4(2): 29-96. doi:10.4054/ DemRes.2001.4.2.

Pittini, A., Ghekiére, L., Dijol, J., and Kiss, I. (2015). The state of housing in the EU 2015. Brussels: Housing Europe.

Sarkisian, N. and Gerstel, N. (2008). Till marriage do us part: Adult children's relationships with their parents. Journal of Marriage and Family 70(2): 360376. doi:10.1111/j.1741-3737.2008.00487.x.

Smits, A., van Gaalen, R.I., and Mulder, C.H. (2010). Parent-child coresidence: Who moves in with whom and for whose needs? Journal of Marriage and Family 72(4): 1022-1033. doi:10.1111/j.1741-3737.2010.00746.x. 
South, S.J. and Lei, L. (2015). Failures-to-launch and boomerang kids: Contemporary determinants of leaving and returning to the parental home. Social Forces 94(2): 863-890. doi:10.1093/sf/sov064.

Stephens, M. (2004). Role of housing finance in the housing policy of the transition country. Paper presented at the Eastern European Workshop on Housing Finance and Housing Affordability, Budapest, Hungary, May 24-25, 2004.

Stone, J., Berrington, A., and Falkingham, J. (2014). Gender, turning points and boomerangs: Returning home in young adulthood in Great Britain. Demography 51(1): 257-276. doi:10.1007/s13524-013-0247-8.

Sullivan, O. (1986). Housing movements of the divorced and separated. Housing Studies 1(1): 35-48. doi:10.1080/02673038608720561.

Theunis, L., Eeckhaut, M.C.W., and van Bavel, J. (2018). Who leaves the joint home after separation? The role of partners' absolute and relative education in Belgium. European Sociological Review 34(6): 659-674. doi:10.1093/esr/jcy 035 .

Thomas, M.J. and Mulder, C.H. (2016). Partnership patterns and home ownership: A cross-country comparison of Germany, the Netherlands and the United Kingdom. Housing Studies 31(8): 935-963. doi:10.1080/02673037.2016.116 4832 .

Vikat, A., Spéder, Zs., Beets, G., Billari, F.C., Bühler, C., Désesquelles, A., Fokkema, T., Hoem, J.M., MacDonald, A., Neyer, G., Pailhé, A., Pinnelli, A., and Solaz, A. (2007). Generations and Gender Survey (GGS): Towards a better understanding of relationships and processes in the life course. Demographic Research 17(14): 389-440. doi:10.4054/DemRes.2007.17.14.

Wagner, M. and Mulder, C.H. (2015). Spatial mobility, family dynamics, and housing transitions. Kölner Zeitschrift für Soziologie und Sozialpsychologie 67(S1): 111135. doi:10.1007/s11577-015-0327-4.

White, L. (1994). Coresidence and leaving home: Young adults and their parents. Annual Review of Sociology 20: 81-102. doi:10.1146/annurev.so.20.080194. 000501. 


\section{Appendix}

\section{Table A-1: Logistic regression estimates of the probability of a residential change between 2008 and 2011}

\begin{tabular}{|c|c|c|c|c|c|c|}
\hline & \multicolumn{3}{|c|}{ Model 1} & \multicolumn{3}{|c|}{ Model 2} \\
\hline & OR & AME & $\mathbf{p}$ & OR & AME & $\mathbf{p}$ \\
\hline \multicolumn{7}{|c|}{$\begin{array}{l}\text { Change in partnership status between waves } 3 \text { and } 4 \text { and union type } \\
\text { in wave } 3 \text { (main effect) }\end{array}$} \\
\hline Steady single & 0.57 & -0.05 & & 0.75 & -0.04 & \\
\hline Steady relationship, cohabitation & 1.63 & 0.06 & ** & 1.54 & 0.07 & ** \\
\hline Steady relationship, marriage & (ref.) & & & (ref.) & & \\
\hline New relationship & 2.88 & 0.15 & $\dagger$ & 2.58 & 0.14 & $\dagger$ \\
\hline Divorce/separation, cohabitation & 2.82 & 0.15 & $* * *$ & 2.78 & 0.15 & $* * *$ \\
\hline Divorce/separation, marriage & 8.42 & 0.37 & $\star \star \star *$ & 9.74 & 0.31 & *** \\
\hline \multicolumn{7}{|l|}{ Living with parents in wave 3 (main effect) } \\
\hline No & (ref.) & & & (ref.) & & \\
\hline Yes & 0.97 & -0.003 & & 1.08 & -0.01 & \\
\hline \multicolumn{7}{|c|}{$\begin{array}{l}\text { Change in partnership status and union type } \mathrm{x} \text { living with parents } \\
\text { (interaction effect) }\end{array}$} \\
\hline Steady single $\mathrm{x}$ living with parents & & & & 0.60 & -0.04 & \\
\hline Steady relationship, cohabitation $\mathrm{x}$ living with parents & & & & 1.58 & 0.07 & \\
\hline Steady relationship, marriage $\mathrm{x}$ living with parents & & & & (ref.) & & \\
\hline New relationship $\mathrm{x}$ living with parents & & & & 1.43 & 0.07 & \\
\hline Divorce/separation, cohabitation $\mathrm{x}$ living with parents & & & & 1.05 & 0.01 & \\
\hline Divorce/separation, marriage $\mathrm{x}$ living with parents & & & & 0.07 & -0.44 & *** \\
\hline \multicolumn{7}{|l|}{ Sex } \\
\hline Male & (ref.) & & & (ref.) & & \\
\hline Female & 0.97 & -0.003 & & 0.96 & -0.005 & \\
\hline \multicolumn{7}{|l|}{ Birth cohort } \\
\hline $1948-1959$ & (ref.) & & & (ref.) & & \\
\hline $1960-1969$ & 1.54 & 0.04 & ** & 1.58 & 0.04 & ** \\
\hline $1970-1979$ & 2.01 & 0.07 & $* * *$ & 2.09 & 0.08 & $* * *$ \\
\hline $1980-1983$ & 2.84 & 0.12 & $\star \star \star *$ & 3.00 & 0.13 & *** \\
\hline \multicolumn{7}{|l|}{ Parenthood status in wave 3} \\
\hline No children under 19 & (ref.) & & & (ref.) & & \\
\hline Has child(ren) under 19 & 0.80 & -0.03 & $\dagger$ & 0.81 & -0.02 & $\dagger$ \\
\hline \multicolumn{7}{|l|}{ Birth of a child between waves 3 and 4} \\
\hline No & (ref.) & & & (ref.) & & \\
\hline Yes & 1.45 & 0.04 & ** & 1.41 & 0.04 & * \\
\hline \multicolumn{7}{|l|}{ Union duration in wave 3} \\
\hline$\leq 1$ year & 2.28 & 0.14 & ** & 2.35 & 0.14 & * \\
\hline $2-4$ years & (ref.) & & & (ref.) & & \\
\hline $5-10$ years & 0.91 & -0.01 & & 0.92 & -0.01 & \\
\hline 10-20 years & 0.54 & -0.07 & ** & 0.55 & -0.07 & ** \\
\hline $20+$ years & 0.36 & -0.11 & $* * *$ & 0.37 & -0.11 & *** \\
\hline no relationship/no answer & 1.01 & 0.002 & & 0.93 & -0.01 & \\
\hline \multicolumn{7}{|l|}{ Level of education in wave 3} \\
\hline Primary & 0.94 & -0.01 & & 0.94 & -0.01 & \\
\hline Secondary & (ref.) & & & (ref.) & & \\
\hline Tertiary & 1.51 & 0.05 & $* * *$ & 1.53 & 0.05 & ** \\
\hline
\end{tabular}


Murinkó: Housing consequences of divorce and separation in a 'super home ownership' regime

Table A-1: (Continued)

\begin{tabular}{|c|c|c|c|c|c|c|}
\hline & Model 1 & & & Model 2 & & \\
\hline & OR & AME & & OR & AME & \\
\hline \multicolumn{7}{|l|}{ Employment status in wave 3} \\
\hline Employed & (ref.) & & & (ref.) & & \\
\hline Not employed & 1.09 & 0.01 & & 1.14 & 0.01 & \\
\hline \multicolumn{7}{|c|}{ Personal income quintiles in wave 3} \\
\hline The lowest quintile & 1.05 & 0.01 & & 1.03 & 0.003 & \\
\hline 2 & 1.17 & 0.02 & & 1.18 & 0.02 & \\
\hline 3 & (ref.) & & & (ref.) & & \\
\hline 4 & 1.00 & 0.0002 & & 0.98 & -0.002 & \\
\hline The highest quintile & 1.28 & 0.03 & $\dagger$ & 1.27 & 0.03 & $\dagger$ \\
\hline No answer & 1.22 & 0.02 & & 1.17 & 0.02 & \\
\hline \multicolumn{7}{|l|}{ Type of settlement in wave 3} \\
\hline The capital (Budapest) & (ref.) & & & (ref.) & & \\
\hline City & 0.96 & -0.01 & & 0.95 & -0.01 & \\
\hline Town & 0.90 & -0.01 & & 0.91 & -0.01 & \\
\hline Village & 0.73 & -0.03 & $\dagger$ & 0.73 & -0.04 & $\dagger$ \\
\hline \multicolumn{7}{|c|}{ Has garden or terrace in wave 3} \\
\hline No & (ref.) & & & (ref.) & & \\
\hline Yes & 0.75 & -0.03 & * & 0.74 & -0.04 & * \\
\hline Number of rooms in wave 3 & 0.95 & -0.01 & $\dagger$ & 0.94 & -0.01 & $\dagger$ \\
\hline Log likelihood & $-2,127.2$ & & & $-2,113.3$ & & \\
\hline Pseudo $\mathrm{R}^{2}$ & 0.186 & & & 0.191 & & \\
\hline $\mathrm{N}$ & 5,408 & & & 5,408 & & \\
\hline
\end{tabular}

Note: ${ }^{* * \star} \mathrm{p}<0.001,{ }^{* *} \mathrm{p}<0.01,{ }^{*} \mathrm{p}<0.05,+\mathrm{p}<0.1$. OR = odds ratio, AME = average marginal effect. The category 'divorce/separation' also includes respondents who repartnered after union dissolution.

Source: Author's calculations based on data from the Hungarian Generations and Gender Survey (Turning Points of the Life Course Panel Survey) waves 3 (2008) and 4 (2012), respondents aged 25-59 in wave 3 ( $n=5,408$ ).

Table A-2: Multinomial logistic regression estimates of the probability of living with parents again, in private rental or other tenure compared to being a homeowner in wave 4

\begin{tabular}{|c|c|c|c|c|c|c|c|c|c|c|}
\hline & \multicolumn{2}{|c|}{$\begin{array}{l}\text { Owner (base } \\
\text { outcome) }\end{array}$} & \multicolumn{4}{|c|}{ Parental household } & \multicolumn{4}{|c|}{ Private rental or other } \\
\hline & AME & $\mathbf{p}$ & OR & $\mathbf{p}$ & AME & $\mathbf{p}$ & OR & $\mathbf{p}$ & AME & $\mathbf{p}$ \\
\hline \multicolumn{11}{|c|}{$\begin{array}{l}\text { Change in partnership status between waves } 3 \text { and } 4 \\
\text { and union type in wave } 3 \text { (main effect) }\end{array}$} \\
\hline Steady single & -0.04 & & 4.10 & & 0.08 & & 1.06 & & -0.04 & \\
\hline Steady relationship, cohabiting & -0.15 & * & 1.68 & & -0.04 & & 3.59 & ** & 0.19 & ** \\
\hline Steady relationship, married & (ref.) & & & & & & & & & \\
\hline New relationship & 0.08 & & 0.29 & & -0.09 & $\dagger$ & 1.57 & & 0.01 & \\
\hline Divorce/separation, cohabiting & -0.37 & $* * *$ & 11.43 & $* * *$ & 0.07 & & 9.01 & $* * *$ & 0.30 & *** \\
\hline Divorce/separation, married & -0.28 & *** & 6.33 & $* *$ & 0.06 & & 6.35 & $\star \star \star *$ & 0.22 & ** \\
\hline \multicolumn{11}{|l|}{ Sex (main effect) } \\
\hline Male & (ref.) & & & & & & & & & \\
\hline Female & 0.03 & & 2.01 & $\dagger$ & -0.05 & * & 1.75 & & 0.02 & \\
\hline
\end{tabular}


Table A-2: (Continued)

\begin{tabular}{|c|c|c|c|c|c|c|c|c|c|c|}
\hline & \multicolumn{2}{|c|}{$\begin{array}{l}\text { Owner (base } \\
\text { outcome) }\end{array}$} & \multicolumn{4}{|c|}{ Parental household } & \multicolumn{4}{|c|}{ Private rental or other } \\
\hline & AME & $\mathbf{p}$ & OR & $\mathbf{p}$ & AME & $\mathbf{p}$ & OR & $\mathbf{p}$ & AME & $\mathbf{p}$ \\
\hline \multicolumn{11}{|c|}{$\begin{array}{l}\text { Change in partnership status, union type, and sex } \\
\text { (interaction) }\end{array}$} \\
\hline Steady single $x$ female & 0.21 & * & 0.21 & * & -0.17 & * & 0.62 & & -0.03 & \\
\hline Steady relationship, cohabiting $x$ female & 0.14 & & 0.21 & $\dagger$ & -0.10 & $\dagger$ & 0.58 & & -0.04 & \\
\hline Steady relationship, married $x$ female & (ref.) & & & & & & & & & \\
\hline New relationship $\mathrm{x}$ female & 0.19 & * & 0.25 & & -0.06 & & 0.37 & $\dagger$ & -0.13 & $\dagger$ \\
\hline Divorce/separation, cohabiting $x$ female & 0.22 & $\dagger$ & 0.09 & ** & -0.26 & * & 0.51 & & 0.04 & \\
\hline Divorce/separation, married $\mathrm{x}$ female & 0.24 & * & 0.19 & * & -0.16 & $\dagger$ & 0.40 & & -0.08 & \\
\hline \multicolumn{11}{|l|}{ Cohort } \\
\hline $1948-1959$ & (ref.) & & & & & & & & & \\
\hline $1960-1969$ & -0.05 & & 0.90 & & -0.02 & & 1.54 & & 0.07 & \\
\hline $1970-1979$ & -0.11 & $\dagger$ & 1.48 & & 0.02 & & 1.89 & $\dagger$ & 0.09 & $\dagger$ \\
\hline $1980-1983$ & -0.09 & & 1.58 & & 0.03 & & 1.61 & & 0.06 & \\
\hline \multicolumn{11}{|l|}{ Parenthood status in wave 3} \\
\hline No children under 19 & (ref.) & & & & & & & & & \\
\hline Has child(ren) under 19 & -0.10 & * & 1.31 & & 0.01 & & 1.74 & * & 0.09 & * \\
\hline \multicolumn{11}{|l|}{ Birth of a child between waves 3 and 4} \\
\hline No & (ref.) & & & & & & & & & \\
\hline Yes & 0.11 & ** & 0.35 & ** & -0.07 & ** & 0.67 & & -0.04 & \\
\hline \multicolumn{11}{|l|}{ Union duration in wave 3} \\
\hline$\leq 1$ year & -0.19 & * & 2.26 & & 0.05 & & 2.63 & * & 0.14 & $\dagger$ \\
\hline $2-4$ years & (ref.) & & & & & & & & & \\
\hline $5-10$ years & 0.07 & & 0.75 & & -0.01 & & 0.63 & & -0.06 & \\
\hline $10-20$ years & 0.06 & & 0.72 & & -0.02 & & 0.69 & & -0.04 & \\
\hline $20+$ years & -0.07 & & 1.56 & & 0.04 & & 1.33 & & 0.03 & \\
\hline no relationship/no answer & -0.13 & & 1.22 & & -0.01 & & 2.27 & & 0.14 & \\
\hline \multicolumn{11}{|l|}{ Level of education in wave 3} \\
\hline Primary & -0.08 & & 2.07 & * & 0.07 & $\dagger$ & 1.20 & & 0.00 & \\
\hline Secondary & (ref.) & & & & & & & & & \\
\hline Tertiary & 0.05 & & 0.89 & & 0.00 & & 0.72 & & -0.05 & \\
\hline \multicolumn{11}{|l|}{ Personal income quintiles in wave 3} \\
\hline The lowest quintile & -0.05 & & 1.18 & & 0.01 & & 1.29 & & 0.04 & \\
\hline 2 & 0.02 & & 0.58 & & -0.06 & & 1.12 & & 0.04 & \\
\hline 3 & (ref.) & & & & & & & & & \\
\hline 4 & 0.06 & & 0.75 & & -0.02 & & 0.71 & & -0.04 & \\
\hline The highest quintile & 0.02 & & 0.47 & $\dagger$ & -0.07 & * & 1.21 & & 0.06 & \\
\hline No answer & 0.03 & & 0.67 & & -0.04 & & 0.99 & & 0.01 & \\
\hline Log likelihood & -817.1 & & & & & & & & & \\
\hline Pseudo $\mathrm{R}^{2}$ & 0.118 & & & & & & & & & \\
\hline $\mathrm{N}$ & 593 & & 112 & & & & 205 & & & \\
\hline
\end{tabular}

Note: The reference category of the multinominal regression: owner, owner's partner/spouse or owner's other relative (but not child). The category 'divorce/separation' also includes respondents who repartnered after union dissolution. ${ }^{* * *} p<0.001,{ }^{* *} p<0.01,{ }^{*} p<$ $0.05, \dagger p<0.1$. OR = odds ratio, $\mathrm{AME}=$ average marginal effect.

Source: Author's calculations based on data from the Hungarian Generations and Gender Survey (Turning Points of the Life Course Panel Survey) waves 3 (2008) and 4 (2012), respondents aged 25-59 in wave 3 ( $n=5,408)$. 
Murinkó: Housing consequences of divorce and separation in a 'super home ownership' regime 